\title{
INVENTORIES, EMPLOYMENT AND HOURS*
}

\author{
Marzio Galeotti \\ University of Bergamo
}

\author{
Louis J. Maccini \\ Johns Hopkins University
}

\author{
Fabio Schiantarelli \\ Boston College
}

January, 2002

JEL Classification: D24, E23, E24, J23, J24, J32

Keywords: Inventories, Employment, Hours, Labor Adjustment Costs, Procyclical Productivity

*We are very grateful to Robert Chirinko, Arthur Lewbel, Michael Lovell, Ingmar Prucha, John van Reenen, and to the participants of several seminars and conferences for helpful discussions and/or comments on earlier versions of the paper. 


\begin{abstract}
The purpose of this paper is to develop a model that integrates inventory and labor decisions. We extend a model of inventory behavior to include a detailed specification of the role of labor input in the production process and of the costs associated with it. In particular, we distinguish between employment, hours and effort per worker, and allow for adjustment costs associated with employment changes. We assume that the requirement function for effective hours has a general trans-logarithmic form, and derive an estimable system of Euler equations for inventories and employment with implied cross-equation restrictions. The econometric results shed light on several important topics, including the shape of the marginal cost of output and the role of labor hoarding as an explanation of procyclical productivity and the persistence of inventory stocks. Moreover, they raise questions about the adequacy of commonly used specifications such as Cobb-Douglas approximations to the production process and the definition of labor input as the product of employment and effective hours worked per worker.
\end{abstract}




\section{INTRODUCTION}

In the last two decades, extensive research has been done on inventory movements. This research has focused on an analysis of several issues that are important for business cycle research. The issues have been provoked by several stylized facts. One provocative fact is that in aggregate manufacturing and in most industries the variance of production exceeds the variance of sales, which contradicts the basic idea that inventories are held by firms primarily to smooth production relative to sales. This fact raised questions about, and stimulated research on, whether the short-run marginal cost of producing output is upward-sloping, which is a rather important assumption in much of macroeconomics research. A second fact is that estimates of adjustment speeds, which govern the adjustment of actual to "desired" inventory stocks, tend to be very low, or, to put the matter in more contemporary parlance, inventory stocks tend to be quite persistent. This fact spawned research on the question of whether there are important costs to changing the level of output. This is because a shock that perturbs desired inventory stocks will cause inventories to return slowly to desired levels if firms adjust production gradually.

To analyze these issues, the bulk of the literature has utilized a linear-quadratic model. The model assumes that the typical firm minimizes the discounted value of expected costs. Costs consist of production costs that depend on the level of output, convex adjustment costs associated with changes in the level of output, and inventory

\footnotetext{
${ }^{1}$ See Blinder and Maccini [1991a,b] and Ramey and West [1999] for surveys of the literature and the presentation of relevant stylized facts.

${ }^{2}$ Research intended to explain one or both of the stylized facts has been done with models that emphasize stock-out avoidance motives (Blanchard [1983], West [1986], Kahn [1992] and Bils and Kahn [2000]), observable cost shocks in the form of real input prices (Miron and Zeldes [1988] and Durlauf and Maccini
} 
holding costs. To rationalize the shape of short-run production costs, an appeal is typically made to the short-run returns to labor, with diminishing (increasing) returns to labor signifying a rising (decreasing) marginal cost of output. Similarly, to rationalize adjustment costs, an appeal is made to costs attached to changing the labor force in the form of, for example, hiring and firing costs. ${ }^{3}$ A difficulty with the model, however, is that the specification of production costs and adjustment costs is not directly derived from the role of labor input in the production process and from the nature of the labor cost structure the firm faces.

Similarly, extensive research has been done on labor demand over the last couple of decades. One of the aims of this research is to explain procyclical movements in labor productivity. ${ }^{1}$ Potential explanations hinge on technology shocks, labor hoarding or increasing returns. The empirical work on labor demand and procyclical labor productivity has been conducted largely with data for manufacturing industries. These industries, however, hold inventories. Yet, the empirical work that has been done has generally ignored the fact that labor demand decisions by business firms are typically made in an environment in which inventory decisions are made as well.

The issues that have been the focus of both debates--such as, why output appears to fluctuate more than sales, why inventory stocks are so persistent, and why labor

[1995]), unobservable technology shocks (Eichenbaum [1989] and Kollintzas [1995]), and declining marginal production costs (Ramey [1991]).

3 Adjustment costs are of course also associated with changes in the capital stock, but given the high frequency nature of inventory decisions, it is natural to put more emphasis on changes in the labor input.

${ }^{4}$ See Hamermesh [1993] and Rotemberg and Woodford [1999] for surveys. Relevant contributions have been made by Basu [1996], Basu and Kimball [1997], Bernanke and Parkinson [1991], Bils and Cho (1994), Burnside, Eichenbaum and Rebelo [1993], Caballero and Lyons (1992), Chirinko [1995], Fair (1985), Fay and Medoff (1985), Morrison and Berndt (1981), Rotemberg and Summers (1990), and Sbordone [1996].

${ }^{5}$ Note that the early literature, mostly employing flexible accelerator models, recognized the interaction between inventories, employment and hours-See Maccini and Rossana [1984] and Rossana [1990]. 
productivity is procyclical--hinge on the parameter estimates that emerge from the models that have been used in empirical work. Despite considerable empirical research on inventories alone or on movements in labor productivity alone, the issues under debate essentially remain open.

The purpose of this paper is to develop a model that integrates inventory and labor decisions. We extend a model of inventory behavior to include a detailed specification of the production process, the role of labor input in the production process, the structure of labor costs and the nature of adjustment costs for labor. In particular, we distinguish between altering labor input along the extensive and intensive margins, and accordingly decompose labor input into an employment decision — the extensive margin - and hours worked per worker and effort decisions - the intensive margins. The model of course includes as well the benefits and costs of holding inventories. Furthermore, we depart from the standard linear-quadratic inventory model by using a translog approximation to production costs. Alternatively, the model can be thought of as an extension of the models used in the labor demand and labor productivity literature to allow for inventory decisions.

These extensions yield several potential advantages to empirical work on inventories and labor demand. Our model yields a system of Euler equations for inventories and employment with implied cross-equation restrictions. In the empirical work, we estimate the system of Euler equations jointly and impose the cross-equation restrictions. We also obtain a requirement function for actual hours of work that can be estimated jointly with the Euler equations, making full use of the cross equation

\footnotetext{
Haltiwanger and Maccini [1989] study empirically the interaction of inventories, hours, new hires and
} temporary and permanent layoffs. 
restrictions implied by the theoretical model. The joint estimation procedure has two advantages. The first is econometric: it gives rise to a potential gain in efficiency, as more information regarding the structure of the model is used in estimation than in econometric work done with models in the literature on inventories alone or in the literature on labor demand alone. The second is economic: joint estimation of the Euler equations (with or without the hours requirement function) yields estimates of important structural parameters that may differ from those obtained in empirical work with the inventory model alone or the labor demand model alone. This can be helpful in understanding some of the puzzles that are plaguing empirical work on inventory movements and procyclical movements in labor productivity.

The model is estimated with monthly data on the nondurable aggregate and the two-digit industries of U.S. manufacturing that produce to stock. The empirical results reveal the advantages of estimating jointly the Euler equations for inventories and employment. The parameters of the jointly estimated equations are generally quite different from those estimated with the inventory equation alone or the employment equation alone. This has important implications for the critical issues under debate in the inventory literature and in the labor productivity literature. Three in particular standout: First, using a new procedure for estimating the slope of marginal cost, we find evidence that the marginal cost of output is indeed generally upward-sloping, which suggests that other forces are needed to explain why production fluctuates more than sales and why labor productivity is procyclical. Second, the results provide evidence of adjustment costs to labor, which is an important ingredient to labor hoarding as an explanation for the procyclical behavior of labor productivity, and which can help to explain persistent 
movements in inventories. Finally, we find that Cobb-Douglas approximations of the production process and the specification of labor input as the product of employment and effective hours worked per worker, both special cases of our model, are rejected by the data. This suggests that the wide use of such approximations in empirical work, especially in the labor productivity literature, may be leading to incorrect inferences.

The next section of the paper presents the model of inventories, employment, and effective hours that we work with. Succeeding sections report estimates of the parameters of our model and tests of the model with data from the nondurable sector and selected two-digit industries of US manufacturing. A concluding section summarizes the paper and suggests areas for further research.

\section{A MODEL OF INVENTORIES AND EMPLOYMENT}

We begin with the firm's technology, which is represented by the following standard short-run neoclassical production function. Allowing for internal adjustment costs defined in terms of net changes in the quasi-fixed input, we define the production function in terms of value added:

$$
\begin{aligned}
& V A_{t}=Y_{t}-M_{t}=\hat{F}\left(L_{t}, Z_{t}, \Delta L_{t} / L_{t-1}, T_{t}\right) \\
& \hat{F}_{L}, \hat{F}_{Z}, \hat{F}_{T}>0 \quad \hat{F}_{\frac{\Delta L}{L_{-1}}>} \leq 0 \text { as } \frac{\Delta L}{L_{-1}}<0
\end{aligned}
$$

where $V A_{t}$ is value added ${ }^{6}, Y_{t}$ is gross output, $M_{t}$ is the amount of materials and supplies purchased and used in the production process, $L_{t}$ is the number of workers employed by

\footnotetext{
${ }^{6}$ The definition of value added assumes for simplicity that the ratio of materials prices to output prices is constant. An interesting extension of the model is to explore the implications of variable real materials prices and the materials input decision, which we leave for future work.
} 
the firm, $Z_{t}$ is effective hours per worker, and $\Delta L_{t} / L_{t-1}$ is the net growth rate in the firm's workforce. Effective hours worked per worker are defined as $Z_{t}=H_{t} X_{t}$ where $H_{t}$ is the number of hours worked by each worker and $X_{t}$ is work intensity, i.e. the effort level expended by a worker in each hour. ${ }^{\square}$ Note that, contrary to much of the labor productivity literature, we treat employment, which is the extensive margin by which labor input can be varied, as a separate input from effective hours, which is the intensive margin.

The production function of course depends also on the state of technology. Further, in accordance with the concept of a short-run production function, the capital stock is taken as given at each point in time, giving rise to strict concavity of the production function. We denote the variable, $T_{t}$, as the "state of technology", but it is intended to capture both the usual state of technology and the capital stock, which shift the short-run production function over time. We assume these forces change relatively smoothly, and can thus be captured by trend movements. 9

Suppose further that materials usage is proportional to output so that $M_{t}=\lambda Y_{t}$ and substituting into (1-a) yields a production function for gross output:

$$
Y_{t}=\frac{1}{1-\lambda} \hat{F}\left(L_{t}, Z_{t}, \Delta L_{t} / L_{t-1}, T_{t}\right)=F\left(L_{t}, Z_{t}, \Delta L_{t} / L_{t-1}, T_{t}\right)
$$

\footnotetext{
${ }^{7}$ See the recent studies by Basu [1996], Basu and Kimball [1997], and Sbordone [1996] for investigations on the role of effort in explaining the procycilcality of measured productivity. Bils and Khan [2000] also allow for a role for effort in a model that includes inventories but abstracts from the cost of adjusting factors of production.

${ }^{8}$ We also abstract from changes in the utilization of capital. On this issue see Shapiro [1986a], Shapiro [1996], and Basu, Fernald and Shapiro [2001].

${ }^{9}$ Clearly an interesting extension of the model and empirical work is to add investment in the capital stock as a decision variable. See Galeotti, Guiso, Sacks and Schiantarelli [1997] for a model with capital as a fixed factor and labor as a variable factor. A key difficulty here, however, is the lack of monthly data on the capital stock, rendering empirical work difficult. Further, intuition suggests that labor is apt to be a closer
} 
which has the same properties as stated in (1-b), namely:

$$
F_{L}, F_{Z}, F_{T}>0 \quad \hat{F}_{\frac{\Delta L}{L_{-1}}>0} \leq 0 \text { as } \frac{\Delta L}{L_{-1}}<0
$$

Note that strict concavity of the value added production function, (1-a), of course implies strict concavity of the gross output production function, (2-a). We focus on the production function for gross output because, when inventories are introduced below, it is gross output that constitutes additions to finished goods inventories 10 .

The stock of workers is a quasi-fixed factor of production, and thus generates adjustment costs to the firm when it changes its labor force. They reflect the hiring, training and firing costs the firm incurs when it devotes resources to the process of changing its labor force. For simplicity, at this stage, adjustment costs are assumed to be internal to the firm and thus take the form of foregone output. Further, we assume that adjustment costs are convex and associated only with changing employment. ${ }^{12}$ Finally, observe that, in line with existing empirical evidence, we are assuming that the firm incurs no costs of adjusting hours worked per worker.

Solve (2-a) for effective hours worked per worker, $Z_{t}=H_{t} X_{t}$, to obtain an effective hours requirement function:

$$
Z_{t}=H_{t} X_{t}=J\left(Y_{t}, L_{t}, \Delta L_{t} / L_{t-1}, T_{t}\right)
$$

substitute for inventory stocks than the capital stock. We note that, even if adjustment costs for capital are present but are not interrelated with those of labor, the first-order condition for labor we derive still holds.

${ }^{10}$ In this paper, we not only assume that materials usage is proportional to output, we also abstract from the holding of materials and supplies and works-in-progress inventories. See Humphreys, Maccini and Schuh [2001] for an analysis of the materials usage decision and the interaction of inventory holdings at different stages of fabrication. These are extensions that we leave for future work.

${ }^{11}$ Below we experiment with a version of the model with external adjustment costs for labor.

12 We are well aware that there is an extensive literature that suggests the need to depart from symmetric quadratic adjustment costs. See Hamermesh and Pfann [1996] for a review of the literature. In this paper, however, we decided to maintain this hypothesis in order not to depart in too many directions from the 
with:

$$
J_{Y}>0 \quad J_{L}, J_{T}<0 \quad J_{\frac{\Delta L}{L_{-1}}>0} \leq \text { as } \frac{\Delta L}{L_{-1}}<0
$$

where the restrictions in (3-b) follow directly from (2-b). Observe that strict concavity of the gross production function, (2-a), implies strict convexity of the effective hours requirement function, (3-a).

The firm is assumed to minimize the discounted value of its expected real costs, which consist of real labor costs and real inventory holding costs. That is, the firm minimizes

$$
E_{t} \sum_{j=0}^{\infty} \beta^{j}\left[\omega\left(H_{t+j}, X_{t+j}\right) L_{t+j}+\Phi\left(N_{t+j-1}, S_{t+j}\right)\right]
$$

where $\omega\left(H_{t}, X_{t}\right)$ is real labor cost per employee to the firm, $\Phi\left(N_{t-1}, S_{t}\right)$ is the real cost of holding inventories, $N_{t}$ is the stock of real finished goods inventories at the end of period t, $S_{t}$ is real sales, $\beta$ is constant real discount factor, and $E_{t}$ is an expectation operator conditional on information available at time t. We will assume that the firm takes sales as given 14 , which is common in the inventory literature, and to be a price-taker in input markets and thus takes real input prices as given.

We assume that labor costs per worker, $\omega\left(H_{t}, X_{t}\right)$, is increasing in the number of hours worked and effort, and is convex. We will allow below for the existence of an

standard linear quadratic inventory model. Moreover, even with convex adjustment costs, the model is already quite complex. Accounting for non-convexities is thus left for future work.

${ }^{13}$ See, for example, Shapiro [1986b], Bils [1987], Hamermesh [1993].

14 This assumption is stronger than necessary. An alternative is to assume that the firm has price setting power, in which case price or sales is an endogenous variable and the optimality conditions require equality between marginal revenue and marginal cost. In principle one could estimate the condition for sales jointly with the cost minimization conditions. This however, would require making specific assumptions about the structure of demand and the determination the markup of prices over marginal costs. In this paper, we focus 
overtime premium when hours exceed their normal level. The remuneration of effort can be explicit (as in the case of piece rates payment systems, or of bonuses linked to the achievement of production targets) or implicit (as in the case of promotions linked to performance).

Inventory holding costs, $\Phi\left(N_{t-1}, S_{t}\right)$, are assumed to be U-shaped in the stock of inventories, given sales. Inventory holding costs balance two forces. They tend to rise with the stock of inventories, reflecting increased storage costs, insurance costs, etc. On the other hand, they tend to fall with inventory stocks, reflecting the idea that higher inventory stocks, given sales, enable the firm to avoid "stock-outs" and therefore avoid suffering lost sales. The presence of sales in the inventory holding cost function captures the idea of an "accelerationist" motive to holding inventories, as higher expected sales induce the firm to add to inventories to avoid stockouts.

The minimization of the present value of expected total costs, (4), is subject to the effective hours requirement function, (3a), and to the inventory accumulation equation:

$$
N_{t}-N_{t-1}=Y_{t}-S_{t}
$$

where $N_{t-1}$, the initial stock of inventories, is taken as given by the firm.

After some manipulation, the optimality conditions for $H_{t}, X_{t}, N_{t}, L_{t}$ reduce to (3a) and

$$
\begin{gathered}
\frac{\omega_{H}\left(H_{t}, X_{t}\right) H_{t}}{\omega\left(H_{t}, X_{t}\right)}=\frac{\omega_{X}\left(H_{t}, X_{t}\right) X_{t}}{\omega\left(H_{t}, X_{t}\right)} \\
\frac{\omega_{H}\left(H_{t}, X_{t}\right) L_{t}}{X_{t}} J_{Y}\left(Y_{t}, L_{t}, \Delta L_{t} / L_{t-1}, T_{t}\right)+\beta E_{t}\left[\Phi_{N}\left(N_{t}, S_{t+1}\right)\right]
\end{gathered}
$$

only on the cost minimization conditions, and leave extensions of the model to deal with the price/sales decision for future work. 


$$
\begin{gathered}
-\beta E_{t}\left[\frac{\omega_{H}\left(H_{t+1}, X_{t+1}\right) L_{t+1}}{X_{t+1}} J_{Y}\left(Y_{t+1}, L_{t+1}, \Delta L_{t+1} / L_{t}, T_{t+1}\right)\right]=0 \\
\omega\left(H_{t}, X_{t}\right)+\frac{\omega_{H}\left(H_{t}, X_{t}\right) L_{t}}{X_{t}} J_{L}\left(Y_{t}, L_{t}, \Delta L_{t} / L_{t-1}, T_{t}\right) \\
+\frac{\omega_{H}\left(H_{t}, X_{t}\right)}{X_{t}}\left(\frac{L_{t}}{L_{t-1}}\right) J_{\frac{\Delta L}{L_{-1}}}\left(Y_{t}, L_{t}, \Delta L_{t} / L_{t-1}, T_{t}\right) \\
-\beta E_{t}\left[\frac{\omega_{H}\left(H_{t+1}, X_{t+1}\right)}{X_{t+1}}\left(\frac{L_{t+1}}{L_{t}}\right)^{2} J_{\frac{\Delta L}{L_{-1}}}\left(Y_{t+1}, L_{t+1}, \Delta L_{t+1} / L_{t}, T_{t+1}\right)\right]=0
\end{gathered}
$$

where, using (5), output is defined by $Y_{t}=S_{t}+N_{t}-N_{t-1}$.

Condition (6) relates hours worked and effort along the optimal path. ${ }^{1.5}$ It states that the elasticity of the labor cost function with respect to hours must equal the elasticity with respect to effort, as in Basu and Kimball (1997). Under the appropriate conditions (6) implies that effort is an increasing function of the number of hours worked, $X_{t}=X\left(H_{t}\right) .6$ Using this relationship, unobservable effort can be eliminated from the Euler equations in (7) and (8).

Condition (7) is the optimality condition on inventories. It requires the firm to balance the marginal cost of producing a unit of output this period and holding it in inventories with the marginal cost of producing it next period.

\footnotetext{
${ }^{15}$ Note that hours worked per worker, effort, employment and inventories are assumed to be chosen at the same time on the basis of the information set that is available to the firm at time $t$.

${ }^{16}$ More specifically,

$$
\frac{d X_{t}}{d H_{t}}=\frac{\omega_{H}+\omega_{H H} H_{t}-\omega_{H X} X_{t}}{\omega_{X}+\omega_{X X} X_{t}-\omega_{H X} H_{t}}>0
$$
}


Condition (8) is the optimality condition on employment. It requires the firm to equate the marginal gain to acquiring an additional worker with the marginal cost of acquiring an additional worker. The former includes the reduction in cost due to the decrease in the number of hours or effort level required to produce a given level of output when the stock of workers increases (for given adjustment costs). The latter includes both the increase in the remuneration per employee and the net marginal hiring and training costs.

Using the optimality condition between hours and effort along the optimal path, (6), and the effective hours requirement function, (3a), one can solve for $H_{t}$ and $X_{t}$ as a function of output, employment, its growth rate, and the state of technology:

$$
\begin{aligned}
& H_{t}=\hat{H}\left(Y_{t}, L_{t}, \Delta L_{t} / L_{t-1}, T_{t}\right) \\
& X_{t}=\hat{X}\left(Y_{t}, L_{t}, \Delta L_{t} / L_{t-1}, T_{t}\right)
\end{aligned}
$$

Using (9) and (10), labor costs may then be written as:

$$
\begin{aligned}
\omega\left(H_{t}, X_{t}\right) L_{t} & =\omega\left[\hat{H}\left(Y_{t}, L_{t}, \Delta L_{t} / L_{t-1}, T_{t}\right), \hat{X}\left(Y_{t}, L_{t}, \Delta L_{t} / L_{t-1}, T_{t}\right)\right] L_{t} \\
& =C\left(Y_{t}, L_{t}, \Delta L_{t} / L_{t-1}, T_{t}\right),
\end{aligned}
$$

which is short-run production costs.

Before proceeding, it is useful to compare the structure of our model with that of the standard inventory and labor demand models. In contrast with the standard inventory model, we have allowed for an explicit specification of the production process with a distinction between employment, hours worked, and effort per worker, with labor costs

This follows from our assumptions that labor cost per employee is increasing in $H_{t}$ and $X_{t}$ so that $\omega_{H}>0, \omega_{X}>0$, is convex so that $\omega_{H H} \geq 0, \omega_{X X} \geq 0$, and the additional assumptions that $\omega_{H H} H_{t}-\omega_{H X} X_{t} \geq 0$ and $\omega_{X X} X_{t}-\omega_{H X} H_{t} \geq 0$. 
reflecting the need to remunerate these different dimensions of the labor input. In addition, observe that labor costs, which are the analogue to short-run production costs in the standard inventory model, depend, on the stock of the quasi-fixed factor-the number of workers employed - as well as on the level of output. Finally, labor costs incorporate adjustment costs, which are captured by the change in employment and not by the change in output, as it is assumed in a rather ad hoc fashion in the standard model.

In contrast with the standard labor demand model, we have allowed for inventory decisions. In particular, changes in demand or costs, which produce changes in employment, hours worked or effort in the standard model, may be satisfied at least in part by inventory movements in our model. This significantly expands the margins along which the firm may respond to exogenous shifts in demand or costs.

\section{THE TRANSLOG MODEL}

\section{A. General Translogarithmic Specification}

Our empirical objective is to estimate (7) and (8) jointly (with and without the hours requirement function). To accomplish this requires a parameterization of the effective hours requirement function, inventory holding cost and labor costs per worker, to which we now turn. We utilize a translog approximation for the firm's effective hours requirement function. Specifically:

$$
\begin{aligned}
\ln Z_{t}= & \ln H_{t} X_{t}=\alpha_{0}+\alpha_{Y} \ln Y_{t}+\alpha_{L} \ln L_{t}+\alpha_{T} \ln T_{t}+0.5 \gamma_{Y Y}\left(\ln Y_{t}\right)^{2} \\
& +0.5 \gamma_{L L}\left(\ln L_{t}\right)^{2}+0.5 \gamma_{T T}\left(\ln T_{t}\right)^{2}+\gamma_{L Y} \ln L_{t} \ln Y_{t}
\end{aligned}
$$




$$
+\gamma_{Y T} \ln T_{t} \ln Y_{t}+\gamma_{L T} \ln T_{t} \ln L_{t}+0.5 \psi\left(\frac{\Delta L_{t}}{L_{t-1}}\right)^{2}
$$

where the $\alpha_{i}{ }^{\prime} s$ are first-order translog parameters and the $\gamma_{i j}{ }^{\prime} s$ are second-order translog parameters of the production process and $\psi$ is an adjustment cost parameter. Note that to achieve a specification that is parsimonious in the parameters to be estimated we have assumed that hours requirement function is multiplicatively separable in adjustment costs. 17

Inventory holding costs are assumed to be given by:

$$
\Phi\left(N_{t-1}, S_{t}\right)=0.5 \delta\left(\frac{N_{t-1}}{S_{t}}-\theta\right)^{2} S_{t}
$$

with $\delta, \theta>0$. Here, inventory holding costs are assumed to be proportional to sales, implying that marginal inventory holding costs depend on the inventory-sales ratio.

Moreover, we assume that the state of technology contains a deterministic component that grows at a constant rate so that the $\ln T_{t}=\zeta t$. We normalize $\zeta$ to unity so that hereafter $\zeta=1.18$ The state of technology also contains a stochastic component, which will be introduced below.

Finally, labor costs are assumed to take the form:

$$
\omega\left(H_{t}, X_{t}\right) L_{t}=\left\{b_{t}+w_{t}^{s}\left[\bar{H}_{t}+1.5\left(H_{t}-\bar{H}_{t}\right)+\tau\left(X_{t}-\bar{X}_{t}\right)\right]\right\} L_{t}
$$

so that labor costs per employee, $\omega\left(H_{t}, X_{t}\right)$, are assumed to be linear and additively separable in $H_{t}$ and $X_{t}$. Labor costs per employee are the sum of three components.

\footnotetext{
${ }^{17}$ See, for example, Chirinko [1995] for a similar parametrization of the hours requirement function in a model without inventories. See also Considine [1997] for the use of a translog cost function, albeit with a different specification of adjustment costs, in a model of a multi-output firm with inventories.
} 
The first component, $b_{t}$, is the portion of real non-wage compensation per worker that is unrelated to effort. The second component is a function of the number of hours worked. We assume that workers receive a straight wage, $w_{t}^{s}$, when hours worked do not exceed normal hours, $\bar{H}_{t}$. When working overtime, they receive a premium of $50 \%$ over the straight-time wage rate. Finally a last component reflects the remuneration for effort. For simplicity, we will assume that the latter takes the form $w_{t}^{s} \tau\left(X_{t}-\bar{X}_{t}\right)$, where $\bar{X}_{t}$ denotes the normal level of effort and $\tau$ is a positive constant. We will assume that the typical firm chooses to use some overtime, since overtime hours are positive at each point of the sample we will use for estimation.

The compensation schedule, (14), and the optimality condition for hours and effort, (6), imply that effort is proportional to hours where the constant of proportionality is $1.5 / \tau$ That is,

$$
X_{t}=\frac{1.5}{\tau} H_{t}
$$

If we assume further that $\bar{X}_{t}=(1.5 / \tau) \bar{H}_{t}$, then the unobservable effort variable can be eliminated from labor costs, so that labor costs, (14), can be written as a function of hours and employment alone as follows:

$$
\begin{aligned}
\omega\left(H_{t}, X_{t}\right) L_{t} & =\left\{b_{t}+w_{t}^{s}\left[\bar{H}_{t}+3.0\left(H_{t}-\bar{H}_{t}\right)\right]\right\} L_{t} \\
& =b_{t} L_{t}+w_{t}^{s}\left[\frac{\bar{H}_{t}}{H_{t}}+\frac{3.0\left(H_{t}-\bar{H}_{t}\right)}{H_{t}}\right] H_{t} L_{t}
\end{aligned}
$$

\footnotetext{
${ }^{18}$ A normalization is needed because $\zeta$ cannot be separately identified from the parameters of the hours requirement function that involve the state of technology.

${ }^{19}$ Note that an elasticity of unity is well within a one standard deviation interval around the point estimate of 1.12 obtained by Basu and Kimball [1997].
} 


$$
=b_{t} L_{t}+\bar{w}_{t} H_{t} L_{t}
$$

where $\bar{w}_{t}$ denotes the average wage per hour, inclusive of the remuneration of effort. Note that (16) implies that the remuneration of effort in effect results in an increase in the premium paid for overtime hours.

Assuming rational expectations and thus replacing expected values with actual values, the Euler equations for inventories and employment are

$$
\begin{gathered}
\left(\frac{1.5 w_{t}^{s} L_{t} H_{t}}{Y_{t}}\right)\left[\alpha_{Y}+\gamma_{Y Y} \ln Y_{t}+\gamma_{Y L} \ln L_{t}+\gamma_{Y T} t\right]+\beta \delta\left(\frac{N_{t-1}}{S_{t}}-\theta\right) \\
-\beta\left(\frac{1.5 w_{t+1}^{s} L_{t+1} H_{t+1}}{Y_{t+1}}\right)\left[\alpha_{Y}+\gamma_{Y Y} \ln Y_{t+1}+\gamma_{Y L} \ln L_{t+1}+\gamma_{Y T}(t+1)\right]=\xi_{1 t} \\
b_{t}+\bar{w}_{t} H_{t}+1.5 w_{t}^{s} H_{t}\left[\alpha_{L}+\gamma_{L L} \ln L_{t}+\gamma_{Y L} \ln Y_{t}+\gamma_{L T} t\right] \\
+\psi 1.5 w_{t}^{s} H_{t}\left(\frac{\Delta L_{t}}{L_{t-1}}\right)\left(\frac{L_{t}}{L_{t-1}}\right)-\beta \psi 1.5 w_{t+1}^{s} H_{t+1}\left(\frac{\Delta L_{t+1}}{L_{t}}\right)\left(\frac{L_{t+1}}{L_{t}}\right)^{2}=\xi_{2 t}
\end{gathered}
$$

where $\xi_{1 t}$ and $\xi_{2 t}$ are forecast errors.

Observe that (17) and (18) contain a cross-equation restriction in that $\gamma_{Y L}$ appears in both equations. An advantage of estimating the inventory and employment Euler equations jointly is that no special normalization is needed to identify and interpret

\footnotetext{
${ }^{20}$ If we assume that the effort related component of remuneration is $w_{t}^{s} \tau X_{t}$, the average cost per hour, $\bar{w}_{t}$, becomes $\bar{w}_{t}=w_{t}^{s}\left[\frac{\bar{H}_{t}}{H_{t}}+\frac{3.0\left(H_{t}-\bar{H}_{t}\right)}{H_{t}}\right]$.
} 
parameters. This is in contrast to the standard linear-quadratic inventory model. The reason is that labor costs are measured in labor cost per worker, so that the parameters of the employment Euler equation are identified and are measured in terms of units of labor costs. ${ }^{2 .}$ Given that there is a cross-equation restriction, namely, that $\gamma_{Y L}$ must be the same in both equations, and that the inventory and employment equations are estimated jointly, the parameters of the inventory equation are identified as well and are measured in terms of units of labor costs. This is a real advantage as it enables us to avoid issues regarding appropriate normalizations that are needed to interpret parameter estimates and that have plagued debates in the inventory literature.

Finally, applying (15) to (12) to eliminate effort, we derive a requirement function for hours worked, which is

$$
\begin{aligned}
\ln H_{t}= & \frac{1}{2}\left\{\bar{\alpha}_{0}+\alpha_{Y} \ln Y_{t}+\alpha_{L} \ln L_{t}+\alpha_{T} t+0.5 \gamma_{Y Y}\left(\ln Y_{t}\right)^{2}+0.5 \gamma_{L L}\left(\ln L_{t}\right)^{2}\right. \\
& \left.+0.5 \gamma_{T T} t^{2}+\gamma_{L Y} \ln L_{t} \ln Y_{t}+\gamma_{Y T} t \ln Y_{t}+\gamma_{L T} t \ln L_{t}+0.5 \psi\left(\frac{\Delta L_{t}}{L_{t-1}}\right)^{2}\right\}+\xi_{3 t}
\end{aligned}
$$

where $\bar{\alpha}_{0}=\alpha_{0}-\ln (1.5 / \tau)$ and $\xi_{3 t}$ is the stochastic component to the state of technology. Equation (19) can be estimated jointly with the Euler equations (17) and (18), yielding a system of three equations with a richer set of cross-equations restrictions. Both additivity and linearity of remuneration in effort are essential in deriving equation (19).

\footnotetext{
${ }^{21}$ Observe in particular that in (18) labor cost per worker, $b_{t}+\bar{w}_{t} H_{t}$, appears as a variable without a parameter attached to it. Hence, the parameters of the labor Euler equation are measured in terms of units of labor costs.

${ }^{22}$ Note that the stochastic shock to technology enters the hours requirement function additively, and thus does not appear in (17) and (18).
} 
It is of interest to compare the optimality conditions of our model with variable effort with those of a model in which effort is kept constant (and normalized to one), which is effectively the case in models where effort is ignored. Obviously, the actual hours requirement functions in the two cases are conceptually very different since, in the case of variable effort, the function incorporates not only a technological requirement, but also the positive relationship that holds on the optimal path between hours and effort. Since now an increase in, say, output, given employment, can be satisfied by a combination of an increase in hours and effort, the required increase in hours is smaller. The Euler equations for employment and inventories, on the other hand, would be the same in the two cases, provided that the remuneration of effort is additive and that the observed data on average hourly earnings captures compensation for both overtime and effort. However, in practice, it is unlikely that the observed average hourly earnings data is inclusive of all the forms of remuneration for effort. In any case, a model with constant effort would not be able to account for the procyclical nature of observed labor productivity (or total factor productivity).

\section{B. Empirical Results: General Translog Model}

We now present the empirical results for the general translog model. To estimate the model, we use monthly data on inventories, sales, hours and employment from the nondurable sector of the manufacturing sector of the US economy for the period 1959.6-1994.3. We work with both the nondurable aggregate and the two-digit industries 
within the nondurables sector that produce to stock. ${ }^{23}$ The inventory and sales data are published by the Bureau of Economic Analysis. They are seasonally adjusted and expressed in constant 1987 dollars. The employment, hours and wage data are from the Bureau of Labor Statistics establishment survey, and refer to production workers, and the non-wage costs are data for fringe benefits from the U.S. Chamber of Commerce at

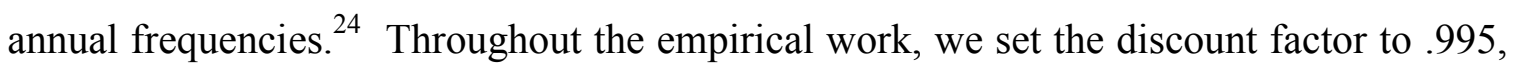
which is equivalent to an annualized discount rate of $6 \%$.

To estimate the model, we first apply GMM to the Euler equations, (17) and (18). $\frac{25}{6}$ We note that all the structural parameters of interest can be estimated from (17) and (18) alone. The instrument sets include output, average hourly earnings, the wage bill, the inventory-sales ratio, the share of labor in output, fringe benefits, and the growth rate of employment, all lagged at least once. Moreover, we have allowed for heteroskedasticity and MA(1) error structures.

Joint estimation of the two Euler equations allows for interaction between the inventory and employment decisions. This is accomplished by imposing the crossequation restriction on $\gamma_{Y L}$, which is the only parameter that is common to both Euler equations, in the estimation process. We start from the specification in which actual average hourly earnings is assumed to capture the remuneration for effort as well as that for overtime in the Euler equation for employment. The results are reported in Table I, where each column corresponds to different instruments sets. However, some of the

\footnotetext{
${ }^{23}$ Empirical work with durable goods industries requires extending the model to allow for the firm to hold work-in-progress and materials and supplies inventories. As Humphreys, Maccini and Schuh [2001] show, such input inventories are relatively more important in durable goods industries.

${ }^{24}$ We use the number of production workers for consistency with the available monthly wage data. All data are seasonally adjusted, with the exception of the straight wage data that does not display any pronounced seasonal pattern.
} 
remuneration for effort (such as production bonuses) is not well captured by the average hourly earnings data provided by BLS. The alternative is to use the functional form for remuneration per worker implied by the model. Below, we present results based on this alternative formulation of remuneration per worker.

The parameter estimates obtained with the specification of the model reported in Table I are very supportive of the model. All the parameters are fairly precisely estimated and have the predicted sign, whenever the theory yields a definitive prediction. Moreover, the parameter estimates are robust to the dating of the instrument set. Column 1 reports the estimates when the instrument set contains variables lagged once, twice and three times, which we refer to as Instrument Set $A_{2}^{26}$ We have also estimated the model with the instruments lagged at least twice, which is labeled Instrument Set B. The results produced virtually identical parameter estimates and significance levels. These are presented in Column 2. Finally, to check for an excessive number of instruments, we also estimated the model with the instruments lagged only twice and three times. This is labeled Instrument Set C, and again it produced very similar parameter estimates and significance levels. Henceforth, for the sake of brevity, we will generally present results with Instrument Set B which contains three lags of the instruments beginning with the variables lagged twice, knowing that the results are quite robust to this choice.

Estimates of $\theta$, the target inventory-sales ratio, and $\delta$, the slope of marginal inventory holding costs, are significant and of reasonable size. The target inventory-sales ratio in particular indicates that firms hold finished goods inventories equal to about three

\footnotetext{
${ }^{25}$ The Euler equations are heavily nonlinear in the variables, rendering it impossible to solve the Euler equations for the decision rules and to estimate the parameters of the model with the decision rules.

${ }^{26}$ To be conservative in guarding against correlation between the instruments and the error terms, we have avoided the use of variables dated at time $t$ in the instrument sets.
} 
weeks of sales. These results provide strong evidence for an "accelerator" motive for holding inventories. The labor adjustment cost parameter estimate, $\psi$, is positive and significant at the $5 \%$ level in all the specifications, in accordance with our assumptions of strictly convex adjustment costs for labor. The existence of adjustment costs is a necessary ingredient for labor hoarding, which is a possible explanation for procyclical observed labor productivity. Further, adjustment costs for labor are also useful for rationalizing the persistence of inventory movements. The parameter estimates of the hours requirement function are also consistent with the predictions of the model and tightly estimated. In particular, the first order parameters, $\alpha_{Y}$ and $\alpha_{L}$, are positive and negative respectively and very tightly estimated. However, even the second-order parameters play an important role. Specifically, $\gamma_{Y Y}$ and $\gamma_{L L}$ are positive and significant, while $\gamma_{Y L}$ is negative and very significant. The latter result is especially important, as $\gamma_{Y L}$ is the only parameter that is common to both the inventory and employment Euler equations and thus bears the cross-equation restriction.

We turn now to the convexity of labor costs. The signs and magnitudes of the first and second order parameters of the effective hours requirement function are by themselves neither necessary nor sufficient for determining the convexity of labor costs. The formulae for convexity of labor costs are straightforward to calculate. ${ }^{27}$ Using the parameter estimates from each column of Table I, and evaluating the formulae at sample means, the results for each instrument set are reported at the bottom of each table. They

\footnotetext{
${ }^{27}$ Specifically, the formulae needed to check the convexity of labor costs under the translog specification are: $C_{Y Y}=\left(H / Y^{2}\right)\left[\gamma_{Y Y}+m_{Y}\left(m_{Y}-1\right)\right]>0, \quad C_{L L}=\left(H / L^{2}\right)\left[\gamma_{L L}+m_{L}\left(m_{L}-1\right)\right]>0$, $C_{Y L}=(H / Y L)\left(\gamma_{Y L}+m_{Y} m_{L}\right), \quad \quad D E T=C_{Y Y} C_{L L}-C_{Y L}{ }^{2}>0$, where $m_{Y}=\alpha_{Y}+\gamma_{Y Y} \ln Y+\gamma_{Y L} \ln L+\gamma_{Y T} t$ and $m_{L}=\alpha_{L}+\gamma_{Y L} \ln Y+\gamma_{L L} \ln L+\gamma_{L T} t$.
} 
reveal that labor costs are indeed strictly convex in $Y_{t}$ and $L_{t}$, for a given level of $\Delta L_{t} / L_{t-1}$. More specifically, $C_{Y Y}$ and $C_{L L}$ are positive and significantly different from zero when they are evaluated at the sample means. The fact that $C_{Y Y}$ is positive and significant implies that the marginal cost of output is clearly upward sloping, given the stock of the quasi-fixed factor. Moreover, $C_{Y L}$ is negative and significant. This is expected, given that employment is a quasi-fixed factor which determines the position of short-run marginal cost, and increases in employment should reduce the marginal cost of output. Finally, the second order principal minor of labor costs, denoted by $D E T=C_{Y Y} C_{L L}-C_{Y L}^{2}$, is always positive and significant at the $1 \%$ level in column (1) and at the $10 \%$ level in column (2). These conditions together with convexity of adjustment costs are sufficient to ensure the convexity of labor costs.

Finally, on convexity, it can easily be proven that, for positive values of $\psi, \delta$ and $\theta$, convexity of labor costs in $N_{t}$ and $L_{t}$, for given $\Delta L_{t} / L_{t-1}$, is sufficient to guarantee the overall convexity of the cost function, provided that the change in employment is not too negative.

Consider next the slope of marginal cost with respect to output, which has been debated at length in the inventory literature ${ }^{28}$ As we have stated above, standard assumptions about the production function imply that labor costs are convex in output. Our specification of the slope of marginal cost with respect to output, however, differs from that in the standard linear-quadratic inventory model for two reasons. First, here we

\footnotetext{
${ }^{28}$ See Galeotti, Guiso, Sack and Schiantarelli [1997] for a discussion of the estimation of the slope of marginal cost in the presence of quasi-fixed factors of production. In particular, they point out the need to recognize that production costs depend on the stock of the quasi-fixed factor of production, as well as its change, in calculating the slope of marginal cost.
} 
are keeping the quasi-fixed factor $L_{t}$, constant when varying output, which is accomplished by varying the perfectly variable factor of production-effective hours worked per worker. Second, in the standard inventory model adjustment costs depend upon the change in output, whereas in our model adjustment costs are a function of the change in the number of workers. However, a specification of the slope of marginal cost with respect to output that is closer to that in the standard model is represented by $M C_{Y Y}$ in Table I. $M C_{Y Y}$ is the derivative of the marginal cost of output calculated by allowing the stock of workers as well as effective hours worked per worker to change when output changes, for given adjustment costs. ${ }^{29}$ Again, the results imply that marginal cost is increasing in output: $\mathrm{MC}_{\mathrm{YY}}$ is always positive and has a marginal significance level extremely close to $5 \%$ in Column 2 , which is our preferred result.

A word is in order regarding the quantitative importance of adjustment costs implied by our econometric results: for instance, using the estimates reported in Table I, increasing the workforce for one period by $1 \%$ generates adjustment costs for an additional worker that vary between $65 \%$ (using instrument set A) and 126\% (using

\footnotetext{
${ }^{29}$ In general, to calculate the slope of the marginal cost of output, use (11) to compute

$$
M C_{Y}=C_{Y}+C_{L} \frac{\partial L}{\partial Y}
$$
}

and

$$
M C_{Y Y}=C_{Y Y}+2 C_{Y L} \frac{\partial L}{\partial Y}+C_{L L}\left(\frac{\partial L}{\partial Y}\right)^{2}+C_{L} \frac{\partial^{2} L}{\partial Y^{2}}
$$

The first term in $M C_{Y}$ is the marginal cost of output calculated by varying hours worked per worker. The second term in $M C_{Y}$ is the product of the marginal cost of output calculated by varying the number of workers and the response of the number of workers to a change in output. The latter may be compute from the Euler equation for labor, which is (8) in general, or (18) for the general trans-log model that is used in the empirical work here. 
instrument set C) of the variable monthly wage bill for a worker. So the size of adjustment costs for labor is certainly not trivial, but is not very large either.

The only problematic aspect of the results presented in Table I is the rejection of the test of over-identifying restrictions. Although the rejection is very common in empirical work with the standard model of inventories, the problem reappears in the context of our more complex model.

Finally, as noted above, if some of the remuneration for effort, e.g., production bonuses, is not well captured by average hourly earnings data, then an alternative measure for remuneration per worker is to use the functional form implied by the model and reported in equation (16), i.e., $w_{t}^{s}\left[\bar{H}_{t}+3.0\left(H_{t}-\bar{H}_{t}\right)\right]^{\square}$ We have thus also estimated (17) and (18) with the earnings component of compensation replaced by $w_{t}^{s}\left[\bar{H}_{t}+3.0\left(H_{t}-\bar{H}_{t}\right)\right]$ in (18). The results are presented in Table II. There are very small differences in parameter estimates, especially for the parameters of the hours requirement function, but the broad conclusions from Table I are exactly the same. Given this, in the rest of the paper we will report only the results obtained when we use actual average hourly earnings.

\footnotetext{
${ }^{30}$ A comparison of our results on the size of adjustment costs with those in the literature is not easy, since most empirical studies focusing on labor are done with lower frequency data. Moreover, there is no unique way of assessing the magnitude of adjustment costs, and the results depend crucially upon the rate of change of employment that is assumed in the calculations. That said, using quarterly data for manufacturing, Shapiro [1986b] finds that adjustment costs for production workers are not significantly different from zero, while adjustment costs for non-production workers are significant and quantitatively important. In Chirinko [1995], using annual data for the non-financial business sector, the own adjustment cost parameter for total employment is not significant but the one capturing interrelated adjustment cost with capital is significant. The size of adjustment costs is quantitatively small. The empirical literature, taken together, seems to suggest that labor adjustment costs are not large (see Hamermesh and Pfann [1996]).

31 Remember that equation (16) is derived from the compensation schedule (14) and the optimal relationship between effort and hours worked, (15)
} 


\section{SOME SPECIAL CASES: INTERNAL ADJUSTMENT COSTS}

\section{A. No Cross Equation Restrictions}

In Column 1 of Table III, we investigate an interesting variation of the basic model. In this case, we do not impose the cross-equation restriction implied by the model, namely, that $\gamma_{Y L}$ be the same in both the inventory and employment Euler equations. Specifically, we allow $\gamma_{Y L}$ to take two different values, denoted by $\gamma_{Y L}^{N}$ and $\gamma_{Y L}^{L}$ respectively. This is designed to check the impact of imposing the cross-equation restriction on the other critical parameters of the inventory and employment Euler equations. Note that in this case a normalization is needed to identify the parameters of the inventory equation. For comparison purposes, we set the parameter of the slope of marginal inventory holding costs, $\delta$, equal to its value in Table I.

The results are presented in Column 1 of Table III. The estimated values of $\gamma_{Y L}^{N}$ and $\gamma_{Y L}^{L}$ are both negative and quite significant. Further, conditional on the normalization, they are significantly different from each other and from the value of $\gamma_{Y L}$ estimated when the cross-equation restriction is imposed. A Wald test, reported in Column 1 of Table III, clearly rejects the hypothesis that $\gamma_{Y L}^{N}$ and $\gamma_{Y L}^{L}$ are the same. A consequence of this result is that many of the estimates of the parameters of the model are quite different from those reported in Table I. One that particularly stands out is the parameter that captures the cost of adjusting employment, $\psi$, which is one of the crucial parameters of the model, and which becomes negative and looses significance when the cross-equation restriction is ignored. Another is that labor costs are not strictly convex in 
output and employment, and the slope of the marginal cost of output is actually negative, though not significantly so. These results are quite different from the results in Table I, and suggest that imposing the restrictions implied by the model in estimation is actually quite important to obtain parameter estimates that are consistent with the theory. Failure to impose the restrictions can give rise to incorrect inferences regarding important issues under debate, such as whether adjustment costs and labor hoarding are important in explaining procyclical labor productivity and whether the marginal cost of output is upward-sloping.

\section{B. No Inventories}

Another interesting variation of the model is to explore the effects of ignoring the inventory decision. The literature on labor demand and in particular the recent literature that is focused on explaining procyclical labor productivity has ignored the impact of the fact that manufacturing firms typically hold finished goods inventories. But, if firms hold inventories, our model implies that inventory decisions should interact with labor decisions, and thus estimates of labor Euler equations will in general be affected by whether or not inventory Euler equations are taken into account.

Column 2 of Table III presents the results for a model in which inventories are absent. In this case, production equals sales so that $Y_{t}=S_{t}$, and there is no Euler equation for inventories. ${ }^{32}$ There is of course an Euler equation for employment. Here, the estimates of the first and second order parameters of the effective hours requirement function are again consistent with the theory, and labor costs are clearly convex in the stock of workers. But, the adjustment cost parameter becomes negative and looses its

\footnotetext{
${ }^{32}$ Note that, since in this case output is equal to sales and sales are exogenous, it is not meaningful to calculate the slope of the marginal cost of producing output.
} 
significance, suggesting that it is very fruitful to consider the employment and inventory decisions jointly. Otherwise, incorrect inferences may be drawn regarding the properties of labor demand and the role of adjustment costs.

\section{Cobb-Douglas Model}

In recent empirical work on productivity, the Cobb-Douglas production function has been widely used. Moreover, the Cobb-Douglas production function has de facto become particularly prominent with the tendency in dynamic general equilibrium models to approximate the Euler equations and the production possibility set with their loglinearized counterparts. In the context of our model, the Cobb-Douglas production function yields an implied effective hours requirement function that is a special case of (12) with all the second-order parameters, the $\gamma_{i j}$, set to zero, that is:

$$
\gamma_{Y Y}=\gamma_{L L}=\gamma_{Y L}=\gamma_{T T}=\gamma_{Y T}=\gamma_{L T}=0
$$

We call these the "Cobb-Douglas restrictions".

Observe that the Cobb-Douglas restrictions yield interesting Euler equations. Applying (20) to (17) and (18) implies the following Euler equations:

$$
\alpha_{Y}\left(\frac{w_{t}^{o} L_{t} H_{t}}{Y_{t}}-\beta \frac{w_{t+1}^{o} L_{t+1} H_{t+1}}{Y_{t+1}}\right)+\beta \delta\left(\frac{N_{t-1}}{S_{t}}-\theta\right)=\xi_{1 t}^{c d}
$$

$$
b_{j}+\bar{w}_{j} H_{j}+\alpha_{L} w_{t}^{o}+\psi w_{t}^{o} H_{t}\left(\frac{\Delta L_{t}}{L_{t-1}}\right)\left(\frac{L_{t}}{L_{t-1}}\right)-\beta \psi w_{t+1}^{o} H_{t+1}\left(\frac{\Delta L_{t+1}}{L_{t}}\right)\left(\frac{L_{t+1}}{L_{t}}\right)^{2}=\xi_{2 t}^{c d}
$$

Observe in particular that the Euler equations for inventories and employment are now separable. That is, because $\gamma_{Y L}=0$ by assumption, there are no cross-equation 
restrictions, and thus estimation of (21) will require a normalization. For comparison purposes, we set $\delta$ equal to its value in Table I.

The results from imposing the Cobb-Douglas restrictions are presented in Table IV. We use a Wald statistic to test the hypothesis that the Cobb-Douglas restrictions are satisfied. As the W-Statistic in Column 1 of Table IV indicates, the Cobb-Douglas restrictions are resoundingly rejected. Furthermore, the Cobb-Douglas specification results in a labor requirement function that is non-convex in output, and by implication a declining marginal cost of output, results that are counter to those in Table I when the Cobb-Douglas restrictions are not imposed. These results highlight the role the secondorder parameters play in estimating inventory and employment Euler equations, and they suggest that, at least for this purpose, Cobb-Douglas approximations appear be too strong.

\section{The Worker-Effective Hours Model}

A widely used specification of labor input to the firm is to assume that the production function depends on total worker-effective hours. 33 Specifically, in the literature total worker-effective hours is defined as $A_{t}=Z_{t} L_{t}=H_{t} X_{t} L_{t}$, which means that labor input is the product of hours worked per worker, effort, and the number of workers employed.

With this specification for total worker-effective hours, (2a) becomes

$$
Y_{t}=\tilde{F}\left(H_{t} X_{t} L_{t}, \Delta L_{t} / L_{t-1}, T_{1}\right)=\tilde{F}\left(A_{t}, \Delta L_{t} / L_{t-1}, T_{t}\right)
$$

Now, inverting (23) yields

$$
A_{t}=A\left(Y_{t}, \Delta L_{t} / L_{t-1}, T_{t}\right)
$$

\footnotetext{
${ }^{33}$ See, for example, Sbordone [1996] and Basu and Kimball (1997) in the labor productivity literature.
} 
Applying the translog approximation to (24) and assuming again that the effective hours requirement function is separable in adjustment costs gives

$$
\begin{aligned}
\ln A_{t} & =\alpha_{0}+\alpha_{Y} \ln Y_{j}+\alpha_{T} \ln T_{j}+0.5 \gamma_{Y Y}\left(\ln Y_{j}\right)^{2}+0.5 \gamma_{T T}\left(\ln T_{j}\right)^{2} \\
& +\gamma_{Y T} \ln Y_{j} \ln T_{j}+0.5 \psi\left(\frac{\Delta L_{j}}{L_{j-1}}\right)^{2}
\end{aligned}
$$

Because $\ln A_{t}=\ln H_{t} X_{t} L_{t}=\ln H_{t} X_{t}+\ln L_{t}$, (25) may be written as

$$
\begin{gathered}
\ln H_{t} X_{t}=-\ln L_{t}+\alpha_{0}+\alpha_{Y} \ln Y_{t}+\alpha_{T} \ln T_{t}+0.5 \gamma_{Y Y}\left(\ln Y_{t}\right)^{2}+0.5 \gamma_{T T}\left(\ln T_{t}\right)^{2} \\
+\gamma_{Y T} \ln Y_{t} \ln T_{t}+0.5 \psi\left(\frac{\Delta L_{t}}{L_{t-1}}\right)^{2}
\end{gathered}
$$

which is a special case of (12) with the restrictions

$$
\alpha_{L}=-1 \quad \gamma_{L L}=\gamma_{Y L}=\gamma_{L T}=0
$$

We call these restrictions the "worker-effective hours restrictions".

When the worker-effective hours restrictions are imposed, the Euler equations now become:

$$
\begin{gathered}
\left(\frac{w_{t}^{o} L_{t} H_{t}}{Y_{t}}\right)\left[\alpha_{Y}+\gamma_{Y Y} \ln Y_{t}+\gamma_{Y T} t\right]+\beta \delta\left(\frac{N_{t-1}}{S_{t}}-\theta\right) \\
-\beta\left(\frac{w_{t+1}^{o} L_{t+1} H_{t+1}}{Y_{t+1}}\right)\left[\alpha_{Y}+\gamma_{Y Y} \ln Y_{t+1}+\gamma_{Y T}(t+1)\right]=\xi_{1 t} \\
b_{t}+\bar{w}_{t} H_{t}-w_{t}^{o} H_{t}+\psi w_{t}^{o} H_{t}\left(\frac{\Delta L_{t}}{L_{t-1}}\right)\left(\frac{L_{t}}{L_{t-1}}\right)-\beta \psi w_{t+1}^{o} H_{t+1}\left(\frac{\Delta L_{t+1}}{L_{t}}\right)\left(\frac{L_{t+1}}{L_{t}}\right)^{2}=\xi_{2 t}
\end{gathered}
$$

Again, there is no cross-equation restriction, and thus a normalization is needed to identify the parameters of the inventory equation. As above, we assume the value of $\delta$ is that of Table I. 
The results are presented in Column 2 of Table IV. A Wald test of the workereffective hours restrictions indicates that the restrictions are dramatically rejected. Further, $\alpha_{Y}$ has the wrong sign and is significant, which contradicts the theory. Further, $C_{Y Y}$ is now negative and very significant, which implies that labor costs are concave in output, given employment, which also contradicts the theory. This contrasts with the results above where hours worked per worker and employment enter as separate inputs in the production process; in the latter case, labor costs are convex in output, which is consistent with the theory. Finally, in the worker-effective hours model the coefficient on the adjustment cost parameter is much less precisely estimated. These results therefore suggest that a second order approximation to a production function in which workers and effective hours enter as separate inputs (and not as a product) in the production function is more consistent with the data, particularly when both inventory and employment Euler equations are estimated jointly.

\section{ALTERNATIVE SPECIFICATIONS}

\section{A. External Adjustment Costs}

So far we have assumed that adjustment costs are internal to the firm and consist

of lost output. We will now assume that adjustment costs are external to the firm. In this case, the effective hours requirement function, (3a), becomes

$$
Z_{t}=H_{t} X_{t}=\widehat{J}\left(Y_{t}, L_{t}, T_{t}\right)
$$

which is independent of the growth rate of employment. The corresponding general trans-log approximation is then

$$
\ln Z_{t}=\ln H_{t} X_{t}=\alpha_{0}+\alpha_{Y} \ln Y_{t}+\alpha_{L} \ln L_{t}+\alpha_{T} \ln T_{t}
$$




$$
\begin{aligned}
& +0.5\left[+\gamma_{Y Y}\left(\ln Y_{t}\right)^{2}+\gamma_{L L}\left(\ln L_{t}\right)^{2}+\gamma_{T T}\left(\ln T_{t}\right)^{2}\right] \\
& +\gamma_{L Y} \ln L_{t} \ln Y_{t}+\gamma_{Y T} \ln T_{t} \ln Y_{t}+\gamma_{L T} \ln T_{t} \ln L_{t}
\end{aligned}
$$

The costs the firm minimizes now become

$$
E_{t} \sum_{j=0}^{\infty} \beta^{j}\left[\omega\left(H_{t+j}, X_{t+j}\right) L_{t+j}+w_{t+j}^{s} \frac{\psi}{2}\left(\frac{\Delta L_{t+j}}{L_{t+j-1}}\right)^{2} L_{t+j}+\Phi\left(N_{t+j-1}, S_{t+j}\right)\right]
$$

which includes a term capturing the real external adjustment costs as well as labor costs and inventory holding costs. Note that we are assuming that the adjustment costs are quadratic and proportional to the number of workers employed, are valued at the straighttime hourly wage rate, and depend on the growth rate of employment. The firm now minimizes (32) subject to (30) and (5).

The Euler equation for inventories remains identical to (17), while the one for employment now becomes

$$
\begin{aligned}
b_{t}+\bar{w}_{t} H_{t} & +w_{t}^{o} H_{t}\left[\alpha_{L}+\gamma_{L L} \ln L_{t}+\gamma_{Y L} \ln Y_{t}+\gamma_{L T} t\right] \\
+\psi w_{t}^{s} & {\left[\left(\frac{\Delta L_{t}}{L_{t-1}}\right)\left(\frac{L_{t}}{L_{t-1}}\right)+\frac{1}{2}\left(\frac{\Delta L_{t}}{L_{t-1}}\right)^{2}\right]-\beta \psi w_{t+1}^{s}\left(\frac{\Delta L_{t+1}}{L_{t}}\right)\left(\frac{L_{t+1}}{L_{t}}\right)^{2}=\xi_{2 t}^{e a} }
\end{aligned}
$$

Table V mirrors Table I for the case of external adjustment costs. Results are presented for all three instrument sets. The overall results are very similar to the ones obtained for internal adjustment costs. In reality, some types of adjustment costs are external, while others are internal and take the form of a loss in output, but one has to make a choice in the empirical implementation. Fortunately, the results are very similar to the ones obtained with internal adjustment costs. The only minor difference is that in two out of the three specifications, the adjustment cost parameter $\psi$ is almost, but not 
quite significant at the 5\% level. This suggests, perhaps, that the assumption of internal adjustment costs is a marginally better approximation to reality.

\section{B. Distributed Lags in Adjustment Costs}

So far, current adjustment costs depend solely on the current change in the workforce. However, given that we are working with monthly data, adjustment costs may be incurred in the current period from prior adjustments in the workforce as well, if the costs of expanding or contracting the workforce extend beyond one month. For example, training programs for new workers may easily last more than one month. We thus extend the model by allowing current adjustment costs to depend on the current and the previous month's change in employment. ${ }^{34}$ Specifically, we extend (12) to

$$
\begin{aligned}
\ln Z_{t}= & \ln H_{t} X_{t}=\alpha_{0}+\alpha_{Y} \ln Y_{t}+\alpha_{L} \ln L_{t}+\alpha_{T} \ln T_{t}+0.5 \gamma_{Y Y}\left(\ln Y_{t}\right)^{2} \\
& +0.5 \gamma_{L L}\left(\ln L_{t}\right)^{2}+0.5 \gamma_{T T}\left(\ln T_{t}\right)^{2}+\gamma_{L Y} \ln L_{t} \ln Y_{t} \\
& +\gamma_{Y T} \ln T_{t} \ln Y_{t}+\gamma_{L T} \ln T_{t} \ln L_{t}+0.5 \psi\left(\frac{\Delta L_{t}}{L_{t-1}}+\mu \frac{\Delta L_{t-1}}{L_{t-2}}\right)^{2}
\end{aligned}
$$

with presumably $0<\mu<1$. We expect current adjustment costs to depend relatively more heavily on current changes in the workforce than on lagged changes, which accounts for the prediction on $\mu$. Obviously, when $\mu=0$, (33) reduces to (12).

The Euler equation for inventories, (17), remains unchanged with the new effective hours requirement function, (33), but the Euler equation for employment, (18), now becomes

$$
b_{t}+\bar{w}_{t} H_{t}+w_{t}^{o} H_{t}\left[\alpha_{L}+\gamma_{L L} \ln L_{t}+\gamma_{Y L} \ln Y_{t}+\gamma_{L T} t\right]
$$

\footnotetext{
${ }^{34} \mathrm{We}$ also experimented with a specification with two lags in the change in employment with essentially the same results.
} 


$$
\begin{gathered}
+\psi w_{t}^{o} H_{t}\left(\frac{\Delta L_{t}}{L_{t-1}}+\mu \frac{\Delta L_{t-1}}{L_{t-2}}\right)\left(\frac{L_{t}}{L_{t-1}}\right)+\beta \psi w_{t+1}^{o} H_{t+1}\left(\frac{\Delta L_{t+1}}{L_{t}}+\mu \frac{\Delta L_{t}}{L_{t-1}}\right)\left(\mu \frac{L_{t+1}}{L_{t-1}}-\left(\frac{L_{t+1}}{L_{t}}\right)^{2}\right) \\
-\beta^{2} \psi w_{t+2}^{o} H_{t+2}\left(\frac{\Delta L_{t+2}}{L_{t+1}}+\mu \frac{\Delta L_{t+1}}{L_{t}}\right)\left(\mu \frac{L_{t+2} L_{t+1}}{L_{t}^{2}}\right)=\xi_{2 t}^{\prime}
\end{gathered}
$$

The results from estimating (17) and (18") jointly are presented in Table VI. Again, for comparison purposes, we present results for the same instrument sets used in Table I. Many results are quite similar to those with the model without lags in adjustment costs. The parameters of the inventory holding cost function, the first and second order parameters of the hours requirement function, and the convexity of labor cots are about the same in size and statistical significance. Still, even in this more general model, we find the overidentifying restrictions rejected.

Adjustment costs, however, are now described by a basic parameter, $\psi$, and the weight, $\mu$, attached to the lagged change in employment. The estimate of the basic parameter, $\psi$, is again positive and about the same size as in the basic specification reported in Table I, but it is slightly less precisely estimated. The weight attached to the lagged change in employment, $\mu$ is positive and non-trivial in size, but it is never quite significant, which suggests that lagged changes in employment do not have a strong effect on current adjustment costs. However, collinearity problems may make it difficult to sort out precisely the separate contributions of the current and the lagged change in employment on current adjustment costs. Given the difficulty of picking up a strong influence of lagged employment changes on current adjustment costs, we continue to work with the specification that contains only the effects of current employment changes on current adjustment costs. 


\section{Joint Estimation of the Hours Requirement Function}

Thus far, we have jointly estimated the Euler equations, and in doing so we have imposed a single cross-equation restriction. In particular, in jointly estimating (17) and (18), we have imposed the restriction that $\gamma_{Y L}$ must be the same in the two equations. As indicated above, this has an important effect on the estimates of the other parameters of the model.

There is also the option of using even more fully the restrictions implied by the model, by estimating jointly the Euler equations, (17) and (18), together with the hours requirement function, (19) itself. This dramatically expands the set of cross-equation restrictions, which now require that $\alpha_{Y}, \alpha_{L}, \gamma_{Y Y}, \gamma_{L L}, \gamma_{Y T}, \gamma_{L T}$ and $\psi$ as well as $\gamma_{Y L}$ be the same across equations.

The results of this more complex estimation problem are presented in Table VII. We present results for two cases: One case is where the hours requirement function contains only a linear time trend so that $\gamma_{T T}=0$. Since also the Euler equations for inventories and employment contain a linear trend, it is as if we de-trended linearly all the variables. The other case is where the hours requirement function contains a quadratic time trend as well so that $\gamma_{T T} \neq 0$. Due to space limitations, we present the results for only instrument sets $\mathrm{B}$ and $\mathrm{C}$ for each case, and simply note that, as above, the results for instrument set $\mathrm{A}$ are consistent with those of instrument sets B and C.

The results for the case where the hours requirement function contains only a linear time trend, Columns (1) and (2) in Table VII, are remarkably similar to those in our basic 
specification in Table I, where the hours requirement function was not estimated. ${ }^{35}$ Not surprisingly, the inventory cost function parameters are unaffected by joint estimation of the hours requirement function. Although some differences appear in quantitative magnitudes, the parameters of the hours requirement function are qualitatively similar to their counterparts in Table I in statistical significance, though $\gamma_{L L}$ is not significant. The adjustment cost parameter is now even more precisely determined, pointing to a clear role for adjustment costs. The cost function remains strictly convex, and the marginal cost of output is steadfastly upward sloping.

When we add a quadratic term to the hours requirement function, Columns (3) and (4) in Table VII, its coefficient is significantly different from zero. Certain results are quite similar to the ones obtained when only the two Euler equations for inventories and employment are estimated. The parameters of the inventory cost function, the convexity of labor costs, and the upward slope to marginal cost are qualitatively similar. The parameters of the hours requirement function, however, are affected in two senses: First, $\alpha_{o}, \alpha_{L}$ and $\gamma_{L L}$ reverse themselves in sign, and are all significant. Second, the adjustment cost parameter, $\psi$, is now negative and insignificant. It appears that adding a quadratic time trend to the hours requirement function alters the estimates of the parameters capturing the effects of employment. However, $C_{L L}$ remains positive, very precisely estimated, and almost exactly the same magnitude as in the case where the quadratic term does not appear, so that the hours requirement function and labor costs remain strictly convex in employment.

\footnotetext{
${ }^{35}$ Note that although the coefficient of the linear trend term is positive, the coefficients of the interaction terms between time, on the one hand, and employment and output, on the other are negative. As a result,
} 


\section{EMPIRICAL WORK WITH TWO-DIGIT INDUSTRIES}

We also estimated the model with data from the two-digit industries commonly referred to as industries that produce to stock. These include Tobacco, Apparel and Textiles, Chemicals, Petroleum and Coal, and Rubber and Plastics. The results for the case where the two Euler equations, (17) and (18), are estimated jointly are presented in Table VIII. The results for the case where hours requirements function, (19), is estimated jointly along with the two Euler equations are presented in Table IX.

Consider first the results for the case where just the two Euler equations are estimated jointly, which are presented in Table VIII. The target inventory-sales ratio, $\theta$, is very precisely estimated and has a plausible size in each industry. The target inventory-sales ratio is estimated to be about one month's sales in each industry. The slope of marginal inventory holding costs, $\delta$, however, experienced mixed results, being positive and significant in two industries, but negative and significant in two others. The adjustment cost parameter, $\psi$, is positive in all industries except Petroleum. In the industries where it is positive, $\psi$ exceeds its standard error, though it is only significant at the five percent level in Apparel and Textiles and at the ten percent level in Chemicals. These are also the only two industries in which adjustment costs are economically important. Labor costs are convex in output and employment in all cases except Tobacco. Finally, the slope of marginal cost is positive in all industries except again for Tobacco, but it is significant only in the Apparel and Textiles industry.

Consider next the case where the hours requirement function is estimated along with the Euler equations. The results are presented in Table IX. The results are generally

the effect of time on the hours requirement function is negative for all the observations, as one would expect. The same is true for the model including a quadratic trend as well. 
consistent with those in Table VIII. In at least two respects, however, the results improve. ${ }^{6}$ First, the adjustment cost parameter, $\psi$, in the industries in which it is positive, is now generally more precisely estimated, and except in the Rubber industry it is now statistically significant at at least the five percent level. This provides evidence, beyond the non-durable aggregate, for adjustment costs to labor, and its implications for procyclical labor productivity and the persistence of inventory movements. Second, except again for the Tobacco industry, the slope of marginal cost with respect to output is positive, and is now statistically significant at at least the five percent level in three of the four industries where it is positive. This provides considerable support for the proposition that marginal cost is generally upward-sloping across the two digit industries.

Taking the results of Tables VIII and IX together, we conclude that the results for the two-digit industries are generally consistent with those for the nondurable aggregate. Except for Tobacco, the marginal cost of output clearly slopes upward. There is evidence in favor of adjustment costs for labor, in the sense that the adjustment cost parameter is generally significant, though adjustment costs appear to be quantitatively large in only two industries. The results on inventory holding costs and thus an accelerator motive are more mixed. The target inventory-sales ratio is positive, a plausible size, and very precisely estimated, but the slope of marginal inventory holding costs is negative and significant in several industries.

\section{CONCLUSIONS}

In this paper, we propose a model that focuses on the interaction of inventory decisions and labor input decisions. Unlike the standard inventory model, we carefully

\footnotetext{
${ }^{36}$ The only area where the results deteriorate in comparison with those in Table VII is that the inventory
} 
specify the role of labor in the firm's decision process, including the decomposition of labor input into separate employment and effective hours worked decisions in the production process, the structure of labor costs, and the nature of adjustment costs on labor. Further, we use a translog approximation for labor costs and thus production costs. Unlike the labor demand literature, we allow the firm to take into account inventory positions in making employment and effective hours decisions. The model yields Euler equations for both inventories and employment with implied cross-equation restrictions. The cross-equation restrictions are imposed when the model is estimated with monthly data on the non-durable aggregate and selected two-digit industries of U.S. manufacturing.

The empirical work yields a number of interesting results and implications:

(1) Estimating the Euler equations for inventories and employment jointly so that the cross-equation restrictions are imposed turns out to be extremely important. If the restrictions are not imposed, the parameters of the model on which there are no cross-equation restrictions can change drastically, which can alter dramatically the implications of the model for important debates in the inventory and labor demand literature. When we estimate the hours requirement function (with a linear trend) jointly with the Euler equations for inventory and employment, we get similar parameter estimates and implications.

(2) We find reasonably strong evidence that the short-run marginal cost of producing output is upward-sloping in non-durable manufacturing and all but one two-digit industry. This implies that the evidence does not support the idea that declining short-run marginal cost is why production varies more than sales. Nor does it

holding cost parameter is negative and significant in the Petroleum industry. 
support the idea that short-run increasing returns to labor is an explanation for procyclical labor productivity.

(3) We find considerable evidence that adjustment costs for labor play an important role in inventory and labor demand decisions for the non-durable aggregate and for two of the two digit industries. There is, therefore, some evidence that adjustment costs and labor hoarding are a potential explanation for the procyclical behavior of observed labor (or total factor) productivity and for the persistence of inventory movements.

(4) Certain simplifying assumptions that are often made in the empirical and theoretical literature are rejected by the data. Specifically, the restrictions imposed on the model by a Cobb-Douglas specification are rejected. Similarly, assuming that labor input is measured by the product of employment and effective hours worked per worker, rather than by treating each as separate inputs in the production process, is also rejected. These results also affect inferences regarding the role of adjustment costs in labor productivity movements and the slope of the marginal cost of production.

(5) We find mixed evidence for an "accelerator" motive for holding inventories. The target inventory-sales ratio is very precisely estimated and plausible in all industries. However, the slope of inventory holding costs, while positive in the nondurable aggregate and several two-digit industries, is negative in other industries.

Given that the empirical work demonstrates the importance of looking at the interaction of decisions by the firm, the model and empirical work need to be extended in 
a number of directions. The extensions are also prompted by the fact that the overidentifying restrictions of the model are rejected, suggesting the possibility that some of the simplifying assumptions we have made need to be relaxed. One extension is to expand the margins along which the firm makes decisions to include the capital utilization and investment decisions. However, we note again that a difficulty here is obtaining reliable monthly data on the capital stock. Another is to relax the assumption that the materials input decision is a fixed proportion of output and to allow for inventory decisions at different stages of fabrication, including not only finished goods decisions, which is done here, but also work-in-progress and materials and supplies decisions. This would permit the model to be applied to durable goods industries where work-in-progress and materials and supplies inventories play a relatively more important role. Moreover, it would be interesting, although very complex due to the aggregation difficulties, to allow for fixed components in labor adjustment costs, in addition to the convex component used here. A final extension is to model the pricing decision of firms and to estimate it jointly with the conditions for cost minimization. All this is left for future work. 


\section{REFERENCES}

BASU, S. (1996), "Procyclical Productivity: Increasing Returns or Cyclical Utilization?", Quarterly Journal of Economics, 111, 719-751.

BASU, S. and M. KIMBALL (1997), "Cyclical Productivity with Unobserved Input Variation”, NBER Working Paper Series, No. 5915.

BASU, S, J.G.FERNALD and M.D. SHAPIRO (2001) "Productivity Growth in the 1990s: Technology, Utilization, or Adjustment?", forthcoming Carnegie Rochester Series on Public Policy.

BERNANKE, B.S. and M. PARKINSON (1991) "Procyclical Labor Productivity and Competing Theories of the Business Cycle: Some Evidence from U.S. Interwar Manufacturing Industries", Journal of Political Economy, 99, 438-59.

BILS, M. (1987), "The Cyclical Behavior of Marginal Cost and Price", American Economic Review, 77, 838-855.

Bils, M. and J. O. Cho, (1994), "Cyclical Factor Utilization", Journal of Monetary Economics, 33, 319-354.

BILS, M. and J. KAHN, (2000), "What Inventory Behavior Tells Us about Business Cycles", American Economic Review, 90, 458-481

BLANCHARD, O.J. (1983), "The Production and Inventory Behavior of the American Automobile Industry", Journal of Political Economy, 91, 365-400.

BLINDER, A.S. and L.J. MACCINI (1991a), "The Resurgence of Inventory Research: What Have We Learned?", Journal of Economic Surveys, 5, 291-328.

BLINDER, A.S. and L.J. MACCINI (1991b), "Taking Stock: A Critical Assessment of Recent Research on Inventories", Journal of Economic Perspectives, 5,73-96.

BURNSIDE, C., M.S. EICHENBAUM and S. REBELO (1993) "Labor Hoarding and the Business Cycle', Journal of Political Economy, 101, 245-73.

CABALLERO, R. and R. K. LYONS (1992), "External Effects in U.S. Procyclical Productivity", Journal of Monetary Economics, 29, 209-225.

CHIRINKO, R.S. (1995), "Nonconvexities, Labor Hoarding, Technology Shocks, and Procyclical Productivity. A Structural Econometric Analysis", Journal of Econometrics, 66, 61-98. 
CONSIDINE, T. J., (1997) "Inventories under Joint Production: An Empirical Analysis of Petroleum Refining", Review of Economics and Statistics, 79, 493-502.

DURLAUF, S.N. and L.J. MACCINI (1995), "Measuring Noise in Inventory Models", Journal of Monetary Economics, 36, 65-89.

EICHENBAUM, M.S. (1989), "Some Empirical Evidence on the Production Level and Production Cost Smoothing Models of Inventory Investment", American Economic Review, 79, 853-64.

FAIR, R. (1985), "Excess Labor and the Business Cycle", American Economic Review, $75,239-245$.

FAY, J.A. and J. L. MEDOFF (1985), "Labor and Output over the Business Cycle", American Economic Review, 75, 638-655.

GALEOTTI, M., L. GUISO, B.SACK and F.SCHIANTARELLI (1997),"Production Smoothing and the Shape of the Cost Function", CEPR Discussion Paper Series, No. 1697.

HALTIWANGER, J.C. and L. J. MACCINI (1989), Inventories, Orders, Temporary and Permanent Layoffs: An Econometric Analysis", Carnegie-Rochester Conference Series on Public Policy, 30, 301-366.

HAMERMESH, D.S. (1993), Labor Demand, Princeton: Princeton University Press.

HAMERMESH, D.S. and G.A. PFANN (1996), "Adjustment Costs in Factor Demand", Journal of Economic Literature, 34, 1264-1292.

HUMPHREYS, B. R., L. J. MACCINI and S. SCHUH (2001), "Input and Output Inventories", Journal of Monetary Economics, 47, 347-375.

KAHN, J.A. (1992), "Why Is Production More Volatile Than Sales? Theory and Evidence on the Stockout-Avoidance Motive for Inventory-Holding", Quarterly Journal of Economics, 107, 481-510.

KOLLINTZAS, T. (1995), "A Generalized Variance Bounds Test, with an application to the Holt et al. Inventory Model", Journal of Economic Dynamics and Control, 19, 59-90.

MACCINI, L.J. and R.J. ROSSANA (1984), "Joint Production, Quasi-Fixed Factors of Production, and Investment in Finished Goods Inventories", Journal of Money, Credit, and Banking, 16, 218-236.

MIRON, J.A. and S.P. ZELDES (1988), "Seasonality, Cost Shocks and the Production Smoothing Model of Inventories", Econometrica, 56, 877-908. 
MORRISON, C.J. and E. R. BERNDT (1981), "Short Run Labor Productivity in a Dynamic Model", Journal of Econometrics, 16, 339-365.

PINDYCK, R. and J. J. ROTEMBERG (1983) "Dynamic Factor Demands and the Effects of Energy Prices” American Economic Review, 73, 1066-1079.

RAMEY, V.A. (1991), "Nonconvex Costs and the Behavior of Inventories", Journal of Political Economy, 99, 306-334.

RAMEY, V.A. and K.D. WEST (1999), "Inventories", in J.B. Taylor and M. Woodford (eds.), Handbook of Macroeconomics, Amsterdam: North-Holland.

ROSSANA, R.J. (1990), "Interrelated Demands for Buffer Stocks and Productive Inputs: Estimates for Two-digit Manufacturing Industries", Review of Economics and Statistics, LXXII, 19-29.

ROTEMBERG, J.J. and L. SUMMERS (1990), "Labor Hoarding, Inflexible Prices and Procyclical Productivity", Quarterly Journal of Economics, CV, 851-874

ROTEMBERG, J.J. and M. WOODFORD (1999), "The Cyclical Behavior of Prices and Costs", NBER Working Paper Series, No. 6909, in J.B. Taylor and M. Woodford (eds.), Handbook of Macroeconomics, Amsterdam: North-Holland.

SBORDONE, A.M. (1996), "Cyclical Productivity in a Model of Labor Hoarding", Journal of Monetary Economics, 38, 331-362.

SHAPIRO, M.D. (1986a), "Capital Accumulation and Capital Utilization: Theory and Evidence", Journal of Applied Econometrics, 1, 211-234.

SHAPIRO, M.D. (1986b), “The Dynamic Demand for Capital and Labor", Quarterly Journal of Economics, 101, 513-542.

SHAPIRO, M.D., (1996). Macroeconomic Implications of Variation in the Workweek of Capital, Brookings Papers on Economics Activity, 2, 79-133.

WEST, K.D. (1986), "A Variance Bound Test of the Linear Quadratic Inventory Model", Journal of Political Economy, 94, 374-401. 
TABLE I

Internal Adjustment Costs Model

Earnings per Hour Measure: Average Hourly Earnings Data

\begin{tabular}{|c|c|c|c|}
\hline Parameter & $\begin{array}{c}\text { (1) } \\
\text { Instrument Set A }\end{array}$ & $\begin{array}{c}(2) \\
\text { Instrument Set B }\end{array}$ & $\begin{array}{c}\text { (3) } \\
\text { Instrument Set C }\end{array}$ \\
\hline$\overline{\alpha_{Y}}$ & $\begin{array}{l}2.005^{* * * *} \\
(.349)\end{array}$ & $\begin{array}{l}2.976^{* * * *} \\
(.510)\end{array}$ & $\begin{array}{l}3.570^{* * *} \\
(.684)\end{array}$ \\
\hline$\alpha_{L}$ & $\begin{array}{l}-26.636^{* * *} \\
(8.693)\end{array}$ & $\begin{array}{c}-25.921 * * * \\
(8.839)\end{array}$ & $\begin{array}{c}-26.631 * * * \\
(9.493)\end{array}$ \\
\hline$\gamma_{Y Y}$ & $\begin{array}{l}.121 * * * \\
(.029)\end{array}$ & $\begin{array}{l}.190^{* * * *} \\
(.048)\end{array}$ & $\begin{array}{l}.241^{* * *} \\
(.065)\end{array}$ \\
\hline$\gamma_{\mathrm{LL}}$ & $\begin{array}{l}2.015^{* *} \\
(1.003)\end{array}$ & $\begin{array}{c}1.994^{*} \\
(1.024)\end{array}$ & $\begin{array}{l}2.119^{* *} \\
(1.098)\end{array}$ \\
\hline$\gamma_{\mathrm{YL}}$ & $\begin{array}{l}-.281^{* * *} \\
(.049) \\
\end{array}$ & $\begin{array}{l}-.420 * * * \\
(.074) \\
\end{array}$ & $\begin{array}{l}-.507 * * * \\
(.099) \\
\end{array}$ \\
\hline$\gamma_{\mathrm{YT}}$ & $\begin{array}{l}-.0003^{* * *} \\
(.0001)\end{array}$ & $\begin{array}{l}-.0003^{*} \\
(.0002)\end{array}$ & $\begin{array}{l}-.0004^{*} \\
(.0002)\end{array}$ \\
\hline$\gamma_{\mathrm{LT}}$ & $\begin{array}{l}-.026^{* * * *} \\
(.0003)\end{array}$ & $\begin{array}{l}-.026^{* * *} \\
(.0004)\end{array}$ & $\begin{array}{l}-.026^{* * *} \\
(.0004)\end{array}$ \\
\hline$\psi$ & $\begin{array}{l}44.482^{* *} \\
(22.489)\end{array}$ & $\begin{array}{l}49.962^{* *} \\
(24.071)\end{array}$ & $\begin{array}{l}86.586^{* *} \\
(42.858)\end{array}$ \\
\hline$\theta$ & $\begin{array}{l}.790^{* * *} \\
(.016) \\
\end{array}$ & $\begin{array}{l}.785^{* * * *} \\
(.012) \\
\end{array}$ & $\begin{array}{l}.790^{* * *} \\
(.014)\end{array}$ \\
\hline$\delta$ & $\begin{array}{l}1306.45^{* *} \\
(528.876)\end{array}$ & $\begin{array}{l}2320.81^{* * *} \\
(756.710)\end{array}$ & $\begin{array}{l}2887.63^{* * *} \\
(1009.62)\end{array}$ \\
\hline $\mathrm{C}_{\mathrm{YY}}$ & $\begin{array}{l}114.785^{* * *} \\
(36.819)\end{array}$ & $\begin{array}{l}141.592^{* *} \\
(61.682)\end{array}$ & $\begin{array}{l}177.996^{* *} \\
(86.338)\end{array}$ \\
\hline $\mathrm{C}_{\mathrm{LL}}$ & $\begin{array}{l}56.243^{* * * *} \\
(.265)\end{array}$ & $\begin{array}{l}56.282^{* * * *} \\
(.272)\end{array}$ & $\begin{array}{l}56.187 * * * \\
(.298)\end{array}$ \\
\hline $\mathrm{C}_{\mathrm{YL}}$ & $\begin{array}{c}-17.663^{* *} \\
(7.652)\end{array}$ & $\begin{array}{l}-36.234 * * * \\
(11.585)\end{array}$ & $\begin{array}{l}-47.248^{* * *} \\
(15.867)\end{array}$ \\
\hline$\overline{\mathrm{DET}}$ & $\begin{array}{l}6143.85^{* * *} \\
(2147.57)\end{array}$ & $\begin{array}{c}6656.16^{*} \\
(3628.56)\end{array}$ & $\begin{array}{c}7768.76 \\
(5199.57)\end{array}$ \\
\hline $\mathrm{MC}_{\mathrm{YY}}$ & $\begin{array}{l}146.943^{* * *} \\
(52.089)\end{array}$ & $\begin{array}{l}168.867^{*} \\
(87.121)\end{array}$ & $\begin{array}{l}207.628^{*} \\
(122.850)\end{array}$ \\
\hline$J$ Test & $\begin{array}{c}126.534 \\
{[.000]}\end{array}$ & $\begin{array}{c}124.947 \\
{[.000]}\end{array}$ & $\begin{array}{c}117.862 \\
{[.000]}\end{array}$ \\
\hline
\end{tabular}

Footnotes:

(i) Standard errors are in parentheses, and are estimated with a covariance matrix that allows for heteroscedasticity and MA(1) errors.

(ii) Three asterisks denote significance at the $1 \%$ level; two asterisks denote significance at the 5\% level; and one asterisk denotes significance at the $10 \%$ level.

(iii) Number of observations: 414.

(iv) The $J$ test indicates the Test of Over-identifying Restrictions. P-value in square brackets.

(v) List of instrument in addition to constant and trend:

$\mathrm{IL}_{\mathrm{t}}=W_{t}^{s} L_{t} H_{t} / Y_{t}, N_{t-1} / S_{t}, b_{t}, \bar{W}_{t}, \ln Y_{t}, \bar{W}_{t} H_{t},\left(\Delta L_{t} / L_{t-1}\right)^{2}$

Instrument Sets (A): $\mathrm{IL}_{\mathrm{t}-1,1}, \mathrm{IL}_{\mathrm{t}-2}, \mathrm{IL}_{\mathrm{t}-3 ;} ; \quad$ (B): $\mathrm{IL}_{\mathrm{t}-2,}, \mathrm{IL}_{\mathrm{t}-3}, \mathrm{IL}_{\mathrm{t}-4} ; \quad$ (C): $\mathrm{IL}_{\mathrm{t}-2}, \mathrm{IL}_{\mathrm{t}-3}$ 
TABLE II

Internal Adjustment Costs Model

Earnings per Hour Measure: Functional Form Implied by the Model

\begin{tabular}{|c|c|c|c|}
\hline Parameter & $\begin{array}{c}\text { (1) } \\
\text { Instrument Set A }\end{array}$ & $\begin{array}{c}(2) \\
\text { Instrument Set B }\end{array}$ & $\begin{array}{c}\text { (3) } \\
\text { Instrument Set C }\end{array}$ \\
\hline$\alpha_{\mathrm{Y}}$ & $\begin{array}{l}1.979 * * * \\
(.345)\end{array}$ & $\begin{array}{l}2.944 * * * \\
(.506)\end{array}$ & $\begin{array}{l}3.537 * * * \\
(.681)\end{array}$ \\
\hline$\alpha_{L}$ & $\begin{array}{l}-25.890^{* * * *} \\
(8.681)\end{array}$ & $\begin{array}{c}-25.290 * * * \\
(8.795)\end{array}$ & $\begin{array}{c}-26.062 * * * \\
(9.441)\end{array}$ \\
\hline$\gamma_{Y Y}$ & $\begin{array}{l}.121 * * * \\
(.029) \\
\end{array}$ & $\begin{array}{l}.188^{* * * *} \\
(.048)\end{array}$ & $\begin{array}{l}.240^{* * * *} \\
(.064) \\
\end{array}$ \\
\hline$\gamma_{\mathrm{LL}}$ & $\begin{array}{c}1.920^{*} \\
(1.001)\end{array}$ & $\begin{array}{c}1.912^{*} \\
(1.018)\end{array}$ & $\begin{array}{l}2.044^{*} \\
(1.092)\end{array}$ \\
\hline$\gamma_{\mathrm{YL}}$ & $\begin{array}{l}-.277^{* * *} \\
(.049) \\
\end{array}$ & $\begin{array}{l}-.416^{* * * *} \\
(.073) \\
\end{array}$ & $\begin{array}{l}-.504 * * * \\
(.099) \\
\end{array}$ \\
\hline$\gamma_{\mathrm{YT}}$ & $\begin{array}{l}-.0003 * * \\
(.0001)\end{array}$ & $\begin{array}{l}-.0002 \\
(.0001)\end{array}$ & $\begin{array}{l}-.0004^{*} \\
(.0002)\end{array}$ \\
\hline$\gamma_{\mathrm{LT}}$ & $\begin{array}{l}-.026 * * * \\
(.0003)\end{array}$ & $\begin{array}{l}-.026^{* * * *} \\
(.0004)\end{array}$ & $\begin{array}{l}-.026 * * * \\
(.0004)\end{array}$ \\
\hline$\psi$ & $\begin{array}{l}43.908^{* *} \\
(22.329)\end{array}$ & $\begin{array}{l}48.499^{* *} \\
(23.856)\end{array}$ & $\begin{array}{l}85.256^{* *} \\
(42.470)\end{array}$ \\
\hline$\theta$ & $\begin{array}{l}.789^{* * * *} \\
(.016) \\
\end{array}$ & $\begin{array}{l}.785^{* * *} \\
(.012) \\
\end{array}$ & $\begin{array}{l}.789^{* * * *} \\
(.014)\end{array}$ \\
\hline$\delta$ & $\begin{array}{l}1300.04 * * \\
(523.813) \\
\end{array}$ & $\begin{array}{l}2307.91^{* * *} \\
(750.838) \\
\end{array}$ & $\begin{array}{l}2880.79 * * * \\
(1005.11)\end{array}$ \\
\hline $\mathrm{C}_{\mathrm{YY}}$ & $\begin{array}{l}113.403 * * * \\
(36.477)\end{array}$ & $\begin{array}{l}140.357^{* *} \\
(61.263)\end{array}$ & $\begin{array}{l}177.311^{* *} \\
(86.082)\end{array}$ \\
\hline $\mathrm{C}_{\mathrm{LL}}$ & $\begin{array}{l}56.811^{* * * *} \\
(.265)\end{array}$ & $\begin{array}{l}56.854 * * * \\
(.271)\end{array}$ & $\begin{array}{l}56.760^{* * * *} \\
(.296)\end{array}$ \\
\hline $\mathrm{C}_{\mathrm{YL}}$ & $\begin{array}{c}-17.660^{* *} \\
(7.614)\end{array}$ & $\begin{array}{l}-36.119^{* * *} \\
(11.552)\end{array}$ & $\begin{array}{l}-47.333^{* * *} \\
(15.885)\end{array}$ \\
\hline DET & $\begin{array}{l}\text { 6130.75*** } \\
(2148.53)\end{array}$ & $\begin{array}{c}6675.29^{*} \\
(3640.06)\end{array}$ & $\begin{array}{c}7823.77 \\
(5236.05)\end{array}$ \\
\hline $\mathrm{MC}_{\mathrm{YY}}$ & $\begin{array}{l}144.707^{* * *} \\
(51.366)\end{array}$ & $\begin{array}{l}167.098^{*} \\
(87.145)\end{array}$ & $\begin{array}{l}206.491^{*} \\
(121.924)\end{array}$ \\
\hline$J$ Test & $\begin{array}{c}126.396 \\
{[.000]} \\
\end{array}$ & $\begin{array}{c}124.831 \\
{[.000]} \\
\end{array}$ & $\begin{array}{c}117.820 \\
{[.000]} \\
\end{array}$ \\
\hline
\end{tabular}

Footnotes: see Table I. 


\section{TABLE III \\ Internal Adjustment Costs Model: Special Cases No Cross equation Restrictions Case and No Inventories Case}

\begin{tabular}{|c|c|c|}
\hline Parameter & $\begin{array}{l}(1) \\
\text { No Cross Equation } \\
\text { Restrictions }\end{array}$ & $\begin{array}{c}(2) \\
\text { No Inventories }\end{array}$ \\
\hline$\alpha_{Y}$ & $\begin{array}{l}.764 * * * \\
(.150) \\
\end{array}$ & \\
\hline$\alpha_{\mathrm{L}}$ & $\begin{array}{c}-189.534 * * * \\
(11.449)\end{array}$ & $\begin{array}{c}-188.204 * * * \\
(12.767)\end{array}$ \\
\hline$\gamma_{Y Y}$ & $\begin{array}{l}.069 * * * \\
(.017)\end{array}$ & \\
\hline$\gamma_{\mathrm{LL}}$ & $\begin{array}{l}31.836^{* * *} \\
(1.772)\end{array}$ & $\begin{array}{l}31.283 * * * \\
(1.982)\end{array}$ \\
\hline$\gamma_{Y L}^{N}$ & $\begin{array}{l}-.118 * * * \\
(-.022)\end{array}$ & \\
\hline$\gamma_{Y L}^{L}$ & $\begin{array}{l}-24.950 * * * \\
(1.255)\end{array}$ & \\
\hline$\gamma_{\mathrm{YT}}$ & $\begin{array}{l}.0001^{*} \\
(.00007)\end{array}$ & \\
\hline$\gamma_{\mathrm{LT}}$ & $\begin{array}{l}.028 * * * \\
(.003)\end{array}$ & $\begin{array}{l}.026 * * * \\
(.003)\end{array}$ \\
\hline$\gamma_{\mathrm{SL}}$ & & $\begin{array}{c}-24.068 * * * \\
(1.408)\end{array}$ \\
\hline$\psi$ & $\begin{array}{c}-3.713 \\
(17.898) \\
\end{array}$ & $\begin{array}{l}-13.443 \\
(19.024) \\
\end{array}$ \\
\hline$\theta$ & $\begin{array}{c}.768^{* * * *} \\
(.005)\end{array}$ & \\
\hline $\mathrm{C}_{\mathrm{YY}}$ & $\begin{array}{c}6.536 \\
(26.3450) \\
\end{array}$ & \\
\hline $\mathrm{C}_{\mathrm{LL}}$ & $\begin{array}{c}63.611^{* * *} \\
(.456)\end{array}$ & $\begin{array}{c}63.290 * * * \\
(.528)\end{array}$ \\
\hline$C_{Y L}^{N}$ & $\begin{array}{l}-3874.57 * * * \\
(194.80)\end{array}$ & \\
\hline$C_{Y L}^{L}$ & $\begin{array}{l}-352805.0^{* * *} \\
(38833.9)\end{array}$ & \\
\hline DET & $\begin{array}{l}-.138 \mathrm{E}+10^{* * *} \\
(.221 \mathrm{E}+9)\end{array}$ & \\
\hline$M C_{Y Y}$ & $\begin{array}{l}-113.509 \\
(622.441) \\
\end{array}$ & NA \\
\hline Wald Test & $\begin{array}{c}390.884 \\
{[.000]}\end{array}$ & \\
\hline$J$ Test & $\begin{array}{c}107.634 \\
{[.000]}\end{array}$ & $\begin{array}{c}100.070 \\
{[.000]} \\
\end{array}$ \\
\hline
\end{tabular}

Footnotes: see Table I. In addition:

In column (1) $\delta$ has been normalized to 2320.81, which is the value it takes in column (2) of Table I.

The Wald test refers to the restrictions implied by the models in column (1) and (2) relative to the more general translog model of Table I.

Instrument Set: Instrument set B in both column (1) and (2). 
TABLE IV

Internal Adjustment Costs Model: More Special Cases Cobb-Douglas Model and Workers-Effective Hours Model

\begin{tabular}{|c|c|c|}
\hline Parameter & $\begin{array}{c}\text { (1) } \\
\text { Cobb-Douglas Model }\end{array}$ & $\begin{array}{c}(2) \\
\text { Worker-Effective Hours } \\
\text { Model }\end{array}$ \\
\hline$\alpha_{Y}$ & $\begin{array}{l}.037^{* * *} \\
(.006)\end{array}$ & $\begin{array}{l}-.065^{* *} \\
(.027)\end{array}$ \\
\hline$\alpha_{\mathrm{L}}$ & $\begin{array}{c}-17.117^{* * *} \\
(.127)\end{array}$ & \\
\hline$\gamma_{\mathrm{YY}}$ & & $\begin{array}{l}.018^{* *} \\
(.007)\end{array}$ \\
\hline$\gamma_{\mathrm{YT}}$ & & $\begin{array}{l}.0002^{* * * *} \\
(.00004)\end{array}$ \\
\hline$\psi$ & $\begin{array}{l}255.051^{* * * *} \\
(92.728)\end{array}$ & $\begin{array}{c}502.819 \\
(418.217)\end{array}$ \\
\hline$\theta$ & $\begin{array}{l}.770^{* * * *} \\
(.003) \\
\end{array}$ & $\begin{array}{l}.763 * * \\
(.003) \\
\end{array}$ \\
\hline $\mathrm{C}_{\mathrm{YY}}$ & $\begin{array}{l}-52.911^{* * *} \\
(8.504)\end{array}$ & $\begin{array}{l}-42.058^{* * *} \\
(13.816)\end{array}$ \\
\hline $\mathrm{C}_{\mathrm{LL}}$ & $\begin{array}{l}63.990^{* * *} \\
(0.982)\end{array}$ & \\
\hline $\mathrm{C}_{\mathrm{YL}}$ & $\begin{array}{c}-10.636^{* * *} \\
(1.787)\end{array}$ & \\
\hline DET & $\begin{array}{c}-3498.86^{* * *} \\
(589.438)\end{array}$ & \\
\hline$M C_{Y Y}$ & $\begin{array}{l}-71.627^{* * *} \\
(11.635)\end{array}$ & $\begin{array}{l}.838 \mathrm{E}+38^{* * *} \\
(.166 \mathrm{E}+37)\end{array}$ \\
\hline Wald Test & $\begin{array}{c}9069.148 \\
{[.000]}\end{array}$ & $\begin{array}{c}198708.28 \\
{[.000]}\end{array}$ \\
\hline$J$ Test & $\begin{array}{c}170.898 \\
{[.000]}\end{array}$ & $\begin{array}{c}206.033 \\
{[.000]}\end{array}$ \\
\hline
\end{tabular}

Footnotes: see Table I. In addition:

(i) The Wald test refers to the restrictions implied by the models in column (1) and (2) relative to the more general translog model of Table I.

(ii) List of instrument in addition to constant and trend:

Instrument Set: $\mathrm{IL}_{\mathrm{t}}=W_{t}^{s} L_{t} H_{t} / Y_{t}, N_{t-1} / S_{t}, b_{t}, \bar{W}_{t}, \ln Y_{t}, \overline{W_{t}} H_{t},\left(\Delta L_{t} / L_{t-1}\right)^{2}$, lagged 2, 3, and 4 periods in both columns. 
TABLE V

\section{External Adjustment Costs Model}

\begin{tabular}{|c|c|c|c|}
\hline Parameter & $\begin{array}{c}\text { (1) } \\
\text { Instrument Set A }\end{array}$ & $\begin{array}{c}\text { (2) } \\
\text { Instrument Set B }\end{array}$ & $\begin{array}{c}\text { (3) } \\
\text { Instrument Set C }\end{array}$ \\
\hline$\alpha_{Y}$ & $\begin{array}{l}2.007 * * * \\
(.348)\end{array}$ & $\begin{array}{l}3.007 * * * \\
(.511)\end{array}$ & $\begin{array}{l}3.684 * * * \\
(.708)\end{array}$ \\
\hline$\alpha_{\mathrm{L}}$ & $\begin{array}{c}-26.847 * * * \\
(8.693)\end{array}$ & $\begin{array}{l}-26.443 * * * \\
(8.792)\end{array}$ & $\begin{array}{l}-27.489 * * * \\
(9.370)\end{array}$ \\
\hline$\gamma_{Y Y}$ & $\begin{array}{l}.122 * * * \\
(.029)\end{array}$ & $\begin{array}{l}.192 * * * \\
(.049)\end{array}$ & $\begin{array}{l}.249 * * * \\
(.067)\end{array}$ \\
\hline$\gamma_{L L}$ & $\begin{array}{l}2.040 * * \\
(1.003)\end{array}$ & $\begin{array}{l}2.057 * * \\
(1.018)\end{array}$ & $\begin{array}{l}2.225^{* *} \\
(1.085)\end{array}$ \\
\hline$\gamma_{\mathrm{YL}}$ & $\begin{array}{l}-.281 * * * \\
(.049)\end{array}$ & $\begin{array}{l}-.425 * * * \\
(.074)\end{array}$ & $\begin{array}{l}-.524 * * * \\
(.103)\end{array}$ \\
\hline$\gamma_{\mathrm{YT}}$ & $\begin{array}{l}-.0003 * * \\
(.0001) \\
\end{array}$ & $\begin{array}{l}-.0003 \\
(.0002) \\
\end{array}$ & $\begin{array}{l}-.0004^{*} \\
(.0002)\end{array}$ \\
\hline$\gamma_{\mathrm{LT}}$ & $\begin{array}{l}-.026^{* * *} \\
(.0003)\end{array}$ & $\begin{array}{l}-.026^{* * *} \\
(.0004)\end{array}$ & $\begin{array}{l}-.025 * * * \\
(.0004)\end{array}$ \\
\hline$\psi$ & $\begin{array}{c}6995.84 * \\
(3857.59)\end{array}$ & $\begin{array}{c}7643.77 * \\
(4051.19)\end{array}$ & $\begin{array}{r}13683.4 * * \\
(6938.03)\end{array}$ \\
\hline$\theta$ & $\begin{array}{l}.790 * * * \\
(.016)\end{array}$ & $\begin{array}{l}.785^{* * *} \\
(.012)\end{array}$ & $\begin{array}{l}.790 * * * \\
(.014)\end{array}$ \\
\hline$\delta$ & $\begin{array}{l}1297.13 * * * \\
(530.138)\end{array}$ & $\begin{array}{l}2331.36 * * * \\
(764.116)\end{array}$ & $\begin{array}{l}2946.26^{* * * *} \\
(1043.13)\end{array}$ \\
\hline $\mathrm{C}_{\mathrm{YY}}$ & $\begin{array}{l}114.832 * * * \\
(36.929)\end{array}$ & $\begin{array}{l}142.013 * * \\
(62.357)\end{array}$ & $\begin{array}{l}184.165 * * \\
(89.065)\end{array}$ \\
\hline $\mathrm{C}_{\mathrm{LL}}$ & $\begin{array}{l}56.249 * * * \\
(.266)\end{array}$ & $\begin{array}{l}56.295^{* * * *} \\
(.271)\end{array}$ & $\begin{array}{l}56.214 * * * \\
(.294)\end{array}$ \\
\hline $\mathrm{C}_{\mathrm{YL}}$ & $\begin{array}{c}-17.822 * * \\
(7.668)\end{array}$ & $\begin{array}{l}-36.803 * * * \\
(11.683)\end{array}$ & $\begin{array}{l}-49.009 * * * \\
(16.387)\end{array}$ \\
\hline$\overline{\mathrm{DET}}$ & $\begin{array}{l}6141.55^{* * * *} \\
(2154.68)\end{array}$ & $\begin{array}{l}6640.16^{*} \\
(3670.22)\end{array}$ & $\begin{array}{c}7950.71 \\
(5371.66)\end{array}$ \\
\hline $\mathrm{MC}_{\mathrm{YY}}$ & $\begin{array}{l}146.930^{* * * *} \\
(52.251)\end{array}$ & $\begin{array}{l}168.852^{*} \\
(88.081)\end{array}$ & $\begin{array}{l}213.958^{*} \\
(126.677)\end{array}$ \\
\hline$J$ Test & $\begin{array}{c}126.672 \\
{[.000]}\end{array}$ & $\begin{array}{c}125.269 \\
{[.000]}\end{array}$ & $\begin{array}{c}118.662 \\
{[.000]}\end{array}$ \\
\hline
\end{tabular}

Footnotes: see Table I. 


\section{TABLE VI}

Distributed Lag Internal Adjustment Costs Model

\begin{tabular}{|c|c|c|c|}
\hline Parameter & $\begin{array}{c}\text { (1) } \\
\text { Instrument Set A }\end{array}$ & $\begin{array}{c}\text { (2) } \\
\text { Instrument Set B }\end{array}$ & $\begin{array}{c}\text { (3) } \\
\text { Instrument Set C }\end{array}$ \\
\hline$\alpha_{Y}$ & $\begin{array}{l}1.902 * * * \\
(.339)\end{array}$ & $\begin{array}{l}2.759 * * * \\
(.497)\end{array}$ & $\begin{array}{l}3.574 * * * \\
(.689)\end{array}$ \\
\hline$\alpha_{\mathrm{L}}$ & $\begin{array}{l}-25.226 * * * \\
(8.876)\end{array}$ & $\begin{array}{l}-24.952 * * * \\
(8.969)\end{array}$ & $\begin{array}{l}-27.093 * * * \\
(9.351)\end{array}$ \\
\hline$\gamma_{Y Y}$ & $\begin{array}{l}.119 * * * \\
(.028)\end{array}$ & $\begin{array}{l}.184 * * * \\
(.046)\end{array}$ & $\begin{array}{l}.248^{* * * *} \\
(.066)\end{array}$ \\
\hline$\gamma_{\mathrm{LL}}$ & $\begin{array}{c}1.847^{*} \\
(1.024) \\
\end{array}$ & $\begin{array}{l}1.8871^{* *} \\
(1.037)\end{array}$ & $\begin{array}{l}2.174 * * \\
(1.082)\end{array}$ \\
\hline$\gamma_{\mathrm{YL}}$ & $\begin{array}{l}-.268 * * * \\
(.048) \\
\end{array}$ & $\begin{array}{l}-.393 * * * \\
(.072)\end{array}$ & $\begin{array}{l}-.511 * * * \\
(.100)\end{array}$ \\
\hline$\gamma_{\mathrm{YT}}$ & $\begin{array}{l}-.0004^{*} \\
(.0002) \\
\end{array}$ & $\begin{array}{l}-.0003^{*} \\
(.0002) \\
\end{array}$ & $\begin{array}{l}-.0004^{*} \\
(.0002) \\
\end{array}$ \\
\hline$\gamma_{\mathrm{LT}}$ & $\begin{array}{l}-.0260 * * * \\
(.0003)\end{array}$ & $\begin{array}{l}-.0257 * * * \\
(.0004)\end{array}$ & $\begin{array}{l}-.0255^{* * *} \\
(.0004)\end{array}$ \\
\hline$\psi$ & $\begin{array}{l}48.360 * * \\
(22.509)\end{array}$ & $\begin{array}{c}47.924^{*} \\
(27.227)\end{array}$ & $\begin{array}{c}75.402 \\
(47.327)\end{array}$ \\
\hline$\mu$ & $\begin{array}{c}.244 \\
(.232)\end{array}$ & $\begin{array}{l}.335 \\
(.333)\end{array}$ & $\begin{array}{l}.128 \\
(.283)\end{array}$ \\
\hline$\Theta$ & $\begin{array}{l}.789 * * * \\
(.016)\end{array}$ & $\begin{array}{l}.784 * * * \\
(.012)\end{array}$ & $\begin{array}{l}.789 * * * \\
(.014)\end{array}$ \\
\hline$\delta$ & $\begin{array}{l}1294.75^{* *} \\
(515.79)\end{array}$ & $\begin{array}{l}2245.20^{* * *} \\
(727.11)\end{array}$ & $\begin{array}{l}2938.80^{* * * *} \\
(1037.24)\end{array}$ \\
\hline $\mathrm{C}_{\mathrm{YY}}$ & $\begin{array}{l}112.400 * * * \\
(36.105)\end{array}$ & $\begin{array}{l}138.438 * * * \\
(56.728)\end{array}$ & $\begin{array}{l}184.443 * * \\
(88.381)\end{array}$ \\
\hline $\mathrm{C}_{\mathrm{LL}}$ & $\begin{array}{l}56.196^{* * * *} \\
(.273)\end{array}$ & $\begin{array}{l}56.215^{* * * *} \\
(.276)\end{array}$ & $\begin{array}{l}56.191 * * * \\
(.292)\end{array}$ \\
\hline $\mathrm{C}_{\mathrm{YL}}$ & $\begin{array}{c}-17.271 * * \\
(7.431)\end{array}$ & $\begin{array}{l}-34.542 * * * \\
(11.175)\end{array}$ & $\begin{array}{l}-48.423 * * * \\
(16.206)\end{array}$ \\
\hline DET & $\begin{array}{l}6018.06^{* * * *} \\
(2099.95)\end{array}$ & $\begin{array}{l}6589.17^{*} \\
(3513.86)\end{array}$ & $\begin{array}{c}8019.38 \\
(5331.52) \\
\end{array}$ \\
\hline $\mathrm{MC}_{\mathrm{YY}}$ & $\begin{array}{l}144.307^{* * *} \\
(51.036)\end{array}$ & $\begin{array}{l}166.828^{* * *} \\
(84.528)\end{array}$ & $\begin{array}{l}215.497^{*} \\
(125.808)\end{array}$ \\
\hline$J$ Test & $\begin{array}{c}126.358 \\
{[.000]}\end{array}$ & $\begin{array}{c}123.923 \\
{[.000]}\end{array}$ & $\begin{array}{c}118.205 \\
{[.000]}\end{array}$ \\
\hline
\end{tabular}

Footnotes: see Table I. 
TABLE VII

Joint Estimation of the Hours Requirement Function and the Euler Equations for the Internal Adjustment Costs Model

\begin{tabular}{|c|c|c|c|c|}
\hline \multirow{2}{*}{ Parameter } & \multicolumn{2}{|l|}{ Linear Trend } & \multicolumn{2}{|c|}{ Quadratic Trend } \\
\hline & $\begin{array}{c}\text { (1) } \\
\text { Instrument Set B }\end{array}$ & $\begin{array}{c}\text { (2) } \\
\text { Instrument Set C }\end{array}$ & $\begin{array}{c}\text { (3) } \\
\text { Instrument Set B }\end{array}$ & $\begin{array}{c}\text { (4) } \\
\text { Instrument Set C }\end{array}$ \\
\hline$\alpha_{0}$ & $\begin{array}{l}36.911^{* * *} \\
(8.885)\end{array}$ & $\begin{array}{l}33.060 * * * \\
(10.850)\end{array}$ & $\begin{array}{l}-30.488 * * * \\
(9.259)\end{array}$ & $\begin{array}{l}-25.118 * * \\
(10.372)\end{array}$ \\
\hline$\alpha_{Y}$ & $\begin{array}{l}6.800 * * * \\
(1.591)\end{array}$ & $\begin{array}{l}9.779 * * * \\
(2.135)\end{array}$ & $\begin{array}{l}4.655^{* * *} \\
(.863)\end{array}$ & $\begin{array}{c}6.714 * * * \\
(1.275)\end{array}$ \\
\hline$\alpha_{\mathrm{L}}$ & $\begin{array}{l}-7.629 * * \\
(4.324)\end{array}$ & $\begin{array}{l}-7.320 \\
(5.342)\end{array}$ & $\begin{array}{l}24.382 * * * \\
(4.315)\end{array}$ & $\begin{array}{l}20.926 * * * \\
(4.867)\end{array}$ \\
\hline$\alpha_{\mathrm{T}}$ & $\begin{array}{l}.221 * * * \\
(.005)\end{array}$ & $\begin{array}{l}.216^{* * *} \\
(.007)\end{array}$ & $\begin{array}{l}.235^{* * * *} \\
(.003)\end{array}$ & $\begin{array}{l}.230^{* * * *} \\
(.004)\end{array}$ \\
\hline$\gamma_{\mathrm{YY}}$ & $\begin{array}{l}.865^{* * *} \\
(.158)\end{array}$ & $\begin{array}{l}1.091 * * * \\
(.232)\end{array}$ & $\begin{array}{l}.439 * * * \\
(.093)\end{array}$ & $\begin{array}{l}.578^{* * * *} \\
(.138)\end{array}$ \\
\hline$\gamma_{\mathrm{LL}}$ & $\begin{array}{l}.185 \\
(.547) \\
\end{array}$ & $\begin{array}{l}.335 \\
(.690)\end{array}$ & $\begin{array}{c}-3.684 * * * \\
(.510)\end{array}$ & $\begin{array}{c}-3.156^{* * *} \\
(.585)\end{array}$ \\
\hline$\gamma_{\mathrm{YL}}$ & $\begin{array}{l}-1.101^{* * *} \\
(.234)\end{array}$ & $\begin{array}{l}-1.516^{* * *} \\
(.320)\end{array}$ & $\begin{array}{l}-.706^{* * *} \\
(.130)\end{array}$ & $\begin{array}{l}-.993 * * * \\
(.191)\end{array}$ \\
\hline$\gamma_{\mathrm{TT}}$ & & & $\begin{array}{l}-.00006^{* * *} \\
(.000003)\end{array}$ & $\begin{array}{l}-.00006^{* * *} \\
(.000004)\end{array}$ \\
\hline$\gamma_{\mathrm{YT}}$ & $\begin{array}{l}-.0028^{* * *} \\
(.0005)\end{array}$ & $\begin{array}{l}-.0035^{* * *} \\
(.0007)\end{array}$ & $\begin{array}{l}-.0004 \\
(.0003)\end{array}$ & $\begin{array}{l}-.0005 \\
(.0004)\end{array}$ \\
\hline$\gamma_{\mathrm{LT}}$ & $\begin{array}{l}-.025 * * * \\
(.0005)\end{array}$ & $\begin{array}{l}-.024 * * * \\
(.0008)\end{array}$ & $\begin{array}{l}-.026 * * * \\
(.0004)\end{array}$ & $\begin{array}{l}-.025 * * * \\
(.0005)\end{array}$ \\
\hline$\psi$ & $\begin{array}{l}53.157 * * * \\
(22.258) \\
\end{array}$ & $\begin{array}{l}78.265^{* *} \\
(30.689)\end{array}$ & $\begin{array}{l}-11.096 \\
(15.126)\end{array}$ & $\begin{array}{r}-13.288 \\
(19.531) \\
\end{array}$ \\
\hline$\theta$ & $\begin{array}{l}.842 * * * \\
(.036)\end{array}$ & $\begin{array}{l}.847 * * * \\
(.039)\end{array}$ & $\begin{array}{l}.797 * * * \\
(.011)\end{array}$ & $\begin{array}{l}.801 * * * \\
(.014)\end{array}$ \\
\hline$\delta$ & $\begin{array}{l}5656.32 * * \\
(2555.55)\end{array}$ & $\begin{array}{l}7569.42 * * \\
(3482.74)\end{array}$ & $\begin{array}{l}5651.61 * * * \\
(1418.94)\end{array}$ & $\begin{array}{l}7462.83 * * * \\
(2099.41) \\
\end{array}$ \\
\hline $\mathrm{C}_{\mathrm{YY}}$ & $\begin{array}{l}928.610 * * * \\
(220.276)\end{array}$ & $\begin{array}{l}1279.79 * * * \\
(383.629)\end{array}$ & $\begin{array}{c}309.687 * * * \\
(126.090)\end{array}$ & $\begin{array}{l}491.071 * * \\
(210.893)\end{array}$ \\
\hline $\mathrm{C}_{\mathrm{LL}}$ & $\begin{array}{c}56.397 * * * \\
(.258)\end{array}$ & $\begin{array}{l}56.413 * * * \\
(.298)\end{array}$ & $\begin{array}{l}55.575 * * * \\
(.233)\end{array}$ & $\begin{array}{l}55.715^{* * * *} \\
(.267)\end{array}$ \\
\hline $\mathrm{C}_{\mathrm{YL}}$ & $\begin{array}{l}-132.566^{* * * *} \\
(39.312)\end{array}$ & $\begin{array}{l}-196.659 * * * \\
(54.471)\end{array}$ & $\begin{array}{l}-111.159^{* * * *} \\
(21.016)\end{array}$ & $\begin{array}{c}-160.973 * * * \\
(31.644)\end{array}$ \\
\hline DET & $\begin{array}{c}34797.6^{* *} \\
(11906.5) \\
\end{array}$ & $\begin{array}{c}33522.7^{*} \\
(18055.8) \\
\end{array}$ & $\begin{array}{c}4854.69 \\
(6675.53) \\
\end{array}$ & $\begin{array}{c}1447.61 \\
(10376.8) \\
\end{array}$ \\
\hline $\mathrm{MC}_{\mathrm{YY}}$ & $\begin{array}{l}1094.86^{* * * *} \\
(273.616)\end{array}$ & $\begin{array}{l}1367.18 * * * \\
(428.628) \\
\end{array}$ & $\begin{array}{r}284.233^{* *} \\
(163.022) \\
\end{array}$ & $\begin{array}{c}393.242 \\
(252.093)\end{array}$ \\
\hline$J$ Test & $\begin{array}{c}171.808 \\
{[.000]}\end{array}$ & $\begin{array}{c}166.496 \\
{[.000]}\end{array}$ & $\begin{array}{c}159.774 \\
{[.000]} \\
\end{array}$ & $\begin{array}{c}156.883 \\
{[.000]}\end{array}$ \\
\hline
\end{tabular}

Footnotes: see Table I. 


\section{TABLE VIII}

\section{Production to Stock Industries: Internal Adjustment Costs Model}

\begin{tabular}{|c|c|c|c|c|c|}
\hline Param. & $\begin{array}{c}\text { (1) } \\
\text { Tobacco } \\
\text { (SIC 21) }\end{array}$ & $\begin{array}{c}(2) \\
\text { Apparel and } \\
\text { Textile } \\
\text { (SIC 23) }\end{array}$ & $\begin{array}{c}(3) \\
\text { Chemical } \\
\text { (SIC 28) }\end{array}$ & $\begin{array}{c}(4) \\
\text { Petroleum } \\
\text { and Coal } \\
\text { (SIC 29) }\end{array}$ & $\begin{array}{c}(5) \\
\text { Rubber and } \\
\text { Plastic } \\
\text { (SIC 30) }\end{array}$ \\
\hline$\alpha_{Y}$ & $\begin{array}{l}.011 * * * \\
(.003)\end{array}$ & $\begin{array}{l}.004 \\
(.004) \\
\end{array}$ & $\begin{array}{l}.218^{* * * *} \\
(.039)\end{array}$ & $\begin{array}{l}.033 * * * \\
(.0094)\end{array}$ & $\begin{array}{l}.033 * * * \\
(.0060)\end{array}$ \\
\hline$\alpha_{\mathrm{L}}$ & $\begin{array}{l}37.836^{* * *} \\
(3.551)\end{array}$ & $\begin{array}{l}83.570 * * * \\
(9.870)\end{array}$ & $\begin{array}{l}12.562 * * * \\
(4.228)\end{array}$ & $\begin{array}{l}31.229 * * * \\
(1.896)\end{array}$ & $\begin{array}{c}3.720 \\
(2.339)\end{array}$ \\
\hline$\gamma_{Y Y}$ & $\begin{array}{l}-.00004 \\
(.00019)\end{array}$ & $\begin{array}{l}.0006 * * \\
(.0003)\end{array}$ & $\begin{array}{l}-.010^{* *} \\
(.004)\end{array}$ & $\begin{array}{l}-.0002 \\
(.0008)\end{array}$ & $\begin{array}{c}-.002 * * \\
(.0006)\end{array}$ \\
\hline$\gamma_{\mathrm{LL}}$ & $\begin{array}{c}-11.676^{* * *} \\
(.813)\end{array}$ & $\begin{array}{c}-13.444 * * * \\
(1.370)\end{array}$ & $\begin{array}{c}-3.584 * * * \\
(.669)\end{array}$ & $\begin{array}{c}-8.489 * * * \\
(.393)\end{array}$ & $\begin{array}{c}-2.387 * * * \\
(.398)\end{array}$ \\
\hline$\gamma_{\mathrm{YL}}$ & $\begin{array}{l}-.002 * * * \\
(.0007)\end{array}$ & $\begin{array}{c}.0005 \\
(.0005)\end{array}$ & $\begin{array}{l}-.032 * * * \\
(.006)\end{array}$ & $\begin{array}{l}.0064 * * * \\
(.0019)\end{array}$ & $\begin{array}{l}.005^{* * * *} \\
(.0010)\end{array}$ \\
\hline$\gamma_{\mathrm{YT}}$ & $\begin{array}{l}-.000008^{* * * *} \\
(.000003)\end{array}$ & $\begin{array}{l}-.000004^{* *} \\
(.000002)\end{array}$ & $\begin{array}{l}.000001 \\
(.00002)\end{array}$ & $\begin{array}{l}.000007 * \\
(.000004)\end{array}$ & $\begin{array}{l}-.000005 \\
(.000004)\end{array}$ \\
\hline$\gamma_{\mathrm{LT}}$ & $\begin{array}{l}-.053 * * * \\
(.002) \\
\end{array}$ & $\begin{array}{l}-.044 * * * \\
(.002)\end{array}$ & $\begin{array}{l}-.027 * * * \\
(.0003)\end{array}$ & $\begin{array}{l}-.032 * * * \\
(.0003)\end{array}$ & $\begin{array}{l}-.023 * * * \\
(.0008)\end{array}$ \\
\hline$\psi$ & $\begin{array}{c}3.552 \\
(2.479)\end{array}$ & $\begin{array}{l}57.535^{* *} \\
(23.665)\end{array}$ & $\begin{array}{l}42.333^{*} \\
(24.964)\end{array}$ & $\begin{array}{l}-2.132 \\
(1.846)\end{array}$ & $\begin{array}{c}6.037 \\
(5.457)\end{array}$ \\
\hline$\theta$ & $\begin{array}{l}.570^{* *} \\
(.249)\end{array}$ & $\begin{array}{l}1.142 * * * \\
(.056)\end{array}$ & $\begin{array}{l}1.080 * * * \\
(.057)\end{array}$ & $\begin{array}{l}.764 * * * \\
(.053)\end{array}$ & $\begin{array}{c}1.144 * * * \\
(.141)\end{array}$ \\
\hline$\delta$ & $\begin{array}{c}3.039 \\
(3.968)\end{array}$ & $\begin{array}{l}13.187 * * \\
(6.177)\end{array}$ & $\begin{array}{l}-51.489^{*} \\
(29.033)\end{array}$ & $\begin{array}{l}7.446^{*} \\
(4.463)\end{array}$ & $\begin{array}{c}-13.643 * * \\
(5.963)\end{array}$ \\
\hline $\mathrm{C}_{\mathrm{YY}}$ & $\begin{array}{l}-9.888^{* *} \\
(4.536)\end{array}$ & $\begin{array}{l}22.933 * * * \\
(6.569)\end{array}$ & $\begin{array}{c}13.947 \\
(20.174)\end{array}$ & $\begin{array}{c}2.496 \\
(2.587)\end{array}$ & $\begin{array}{c}47.342 \\
(29.778)\end{array}$ \\
\hline $\mathrm{C}_{\mathrm{LL}}$ & $\begin{array}{c}12625.5^{* * * *} \\
(84.890)\end{array}$ & $\begin{array}{c}226.504 * * * \\
(2.014)\end{array}$ & $\begin{array}{c}730.932 * * * \\
(3.571)\end{array}$ & $\begin{array}{c}5253.44 * * * \\
(22.892)\end{array}$ & $\begin{array}{c}714.272 * * * \\
(3.391)\end{array}$ \\
\hline $\mathrm{C}_{\mathrm{YL}}$ & $\begin{array}{l}-8.230^{* *} \\
(3.884)\end{array}$ & $\begin{array}{c}.106 \\
(.787)\end{array}$ & $\begin{array}{l}20.351 * * * \\
(7.869)\end{array}$ & $\begin{array}{l}5.363 * * \\
(2.351)\end{array}$ & $\begin{array}{l}22.449 * * * \\
(4.848)\end{array}$ \\
\hline$\overline{\text { DET }}$ & $\begin{array}{c}-124909.0^{* *} \\
(57224.1)\end{array}$ & $\begin{array}{l}5194.32 * * * \\
(1480.99)\end{array}$ & $\begin{array}{r}9780.40 \\
(14671.8)\end{array}$ & $\begin{array}{c}13085.7 \\
(13576.9)\end{array}$ & $\begin{array}{c}33310.9 \\
(21097.8)\end{array}$ \\
\hline $\mathrm{MC}_{\mathrm{YY}}$ & $\begin{array}{c}-10.128^{* *} \\
(4.592)\end{array}$ & $\begin{array}{l}23.094 * * * \\
(6.609)\end{array}$ & $\begin{array}{c}11.179 \\
(19.241)\end{array}$ & $\begin{array}{c}3.984 \\
(3.610)\end{array}$ & $\begin{array}{c}36.085 \\
(22.553)\end{array}$ \\
\hline$J$ Test & $\begin{array}{l}43.508 \\
{[.182]}\end{array}$ & $\begin{array}{l}76.773 \\
{[.000]}\end{array}$ & $\begin{array}{c}120.014 \\
{[.000]}\end{array}$ & $\begin{array}{l}87.721 \\
{[.000]}\end{array}$ & $\begin{array}{c}122.432 \\
{[.000]}\end{array}$ \\
\hline
\end{tabular}

Footnotes: see Table 1. In addition:

(i) $\mathrm{MA}(1)$ errors. List of instrument in addition to constant and trend:

Instrument Set: $\mathrm{IL}_{\mathrm{t}}=W_{t}^{s} L_{t} H_{t} / Y_{t}, N_{t-1} / S_{t}, b_{t}, \bar{W}_{t}, \ln Y_{t}, \bar{W}_{t} H_{t},\left(\Delta L_{t} / L_{t-1}\right)^{2}$, lagged 2, 3, and 4 periods.

(ii) Number of observations: 318 for columns (2), and (3); 414 for columns (3), (4) and (5). 


\section{TABLE IX}

\section{Production to Stock Industries:}

Joint Estimation of the Hours Requirement Function and the Euler Equations for the Internal Adjustment Cost Model

\begin{tabular}{|c|c|c|c|c|c|}
\hline Param. & $\begin{array}{c}\text { (1) } \\
\text { Tobacco } \\
\text { (SIC 21) }\end{array}$ & $\begin{array}{c}(2) \\
\text { Apparel and } \\
\text { Textile } \\
\text { (SIC 23) }\end{array}$ & $\begin{array}{c}\text { (3) } \\
\text { Chemical } \\
\text { (SIC 28) }\end{array}$ & $\begin{array}{c}(4) \\
\text { Petroleum } \\
\text { and Coal } \\
\text { (SIC 29) }\end{array}$ & $\begin{array}{c}(5) \\
\text { Rubber and } \\
\text { Plastic } \\
\text { (SIC 30) }\end{array}$ \\
\hline$\alpha_{0}$ & $\begin{array}{l}-16.033 * * * \\
(3.131)\end{array}$ & $\begin{array}{l}39.721 * * * \\
(6.999)\end{array}$ & $\begin{array}{l}-14.100 * * * \\
(3.032)\end{array}$ & $\begin{array}{c}-32.705 * * * \\
(1.437)\end{array}$ & $\begin{array}{l}7.329 * * * \\
(2.033)\end{array}$ \\
\hline$\alpha_{Y}$ & $\begin{array}{l}.150 * * * \\
(.029)\end{array}$ & $\begin{array}{l}.009^{* *} \\
(.004)\end{array}$ & $\begin{array}{l}.224^{*} \\
(.133)\end{array}$ & $\begin{array}{l}-.028 \\
(.042)\end{array}$ & $\begin{array}{l}-.067 * * * \\
(.024)\end{array}$ \\
\hline$\alpha_{\mathrm{L}}$ & $\begin{array}{l}33.730 * * * \\
(2.833)\end{array}$ & $\begin{array}{l}-5.847 \\
(3.898)\end{array}$ & $\begin{array}{l}22.146^{* * *} \\
(1.925)\end{array}$ & $\begin{array}{l}41.420^{* * * *} \\
(1.191)\end{array}$ & $\begin{array}{l}8.130 * * * \\
(1.391)\end{array}$ \\
\hline$\alpha_{\mathrm{T}}$ & $\begin{array}{l}.152 * * * \\
(.007)\end{array}$ & $\begin{array}{l}.146 * * * \\
(.005)\end{array}$ & $\begin{array}{l}.173 * * * \\
(.002)\end{array}$ & $\begin{array}{l}.152 * * * \\
(.001)\end{array}$ & $\begin{array}{l}.168 * * * \\
(.003)\end{array}$ \\
\hline$\gamma_{Y Y}$ & $\begin{array}{c}-.004 * * \\
(.002)\end{array}$ & $\begin{array}{l}.0007 * * * \\
(.0002)\end{array}$ & $\begin{array}{l}-.027 * * * \\
(.010)\end{array}$ & $\begin{array}{l}.019 * * * \\
(.005)\end{array}$ & $\begin{array}{l}-.009 * * * \\
(.002)\end{array}$ \\
\hline$\gamma_{\mathrm{LL}}$ & $\begin{array}{c}-10.805^{* * *} \\
(.645) \\
\end{array}$ & $\begin{array}{c}-1.032^{*} \\
(.543)\end{array}$ & $\begin{array}{l}-5.080 * * * \\
(.306)\end{array}$ & $\begin{array}{l}-10.578 * * * \\
(.248)\end{array}$ & $\begin{array}{c}-3.092 * * * \\
(.235)\end{array}$ \\
\hline$\gamma_{\mathrm{YL}}$ & $\begin{array}{l}-.033 * * * \\
(.006)\end{array}$ & $\begin{array}{l}-.001^{* *} \\
(.0005) \\
\end{array}$ & $\begin{array}{l}-.020 \\
(.022)\end{array}$ & $\begin{array}{c}.004 \\
(.009) \\
\end{array}$ & $\begin{array}{l}.013^{* * * *} \\
(.004)\end{array}$ \\
\hline$\gamma_{\mathrm{YT}}$ & $\begin{array}{l}-.0001 * * * \\
(.00003)\end{array}$ & $\begin{array}{l}-.000009^{* * * *} \\
(.000002)\end{array}$ & $\begin{array}{l}-.0003 * * * \\
(.00005)\end{array}$ & $\begin{array}{l}-.0001 * * * \\
(.00003)\end{array}$ & $\begin{array}{l}-.00006 * * * \\
(.00002)\end{array}$ \\
\hline$\gamma_{\mathrm{LT}}$ & $\begin{array}{l}-.050 * * * \\
(.002)\end{array}$ & $\begin{array}{l}.025^{* * *} \\
(.0008)\end{array}$ & $\begin{array}{l}-.027 * * * \\
(.0003)\end{array}$ & $\begin{array}{l}-.034 * * * \\
(.0002)\end{array}$ & $\begin{array}{l}-.022 * * * \\
(.0005)\end{array}$ \\
\hline$\psi$ & $\begin{array}{l}3.954 * * \\
(1.665)\end{array}$ & $\begin{array}{l}33.772 * * \\
(13.951)\end{array}$ & $\begin{array}{l}88.647 * * * \\
(28.384)\end{array}$ & $\begin{array}{l}-2.631 * * \\
(1.305)\end{array}$ & $\begin{array}{c}2.034 \\
(3.895)\end{array}$ \\
\hline$\theta$ & $\begin{array}{l}.359 * * * \\
(.015)\end{array}$ & $\begin{array}{l}1.211 * * * \\
(.070)\end{array}$ & $\begin{array}{c}1.080 \\
-\end{array}$ & $\begin{array}{l}.614^{* * * *} \\
(.024)\end{array}$ & $\begin{array}{l}.896^{* * * *} \\
(.045)\end{array}$ \\
\hline$\delta$ & $\begin{array}{l}224.454 * * * \\
(47.464)\end{array}$ & $\begin{array}{l}14.403 * * \\
(5.865)\end{array}$ & $\begin{array}{c}-244.246 * * * \\
(86.010)\end{array}$ & $\begin{array}{c}-115.147 * * * \\
(28.915)\end{array}$ & $\begin{array}{l}-86.734 * * * \\
(29.709)\end{array}$ \\
\hline $\mathrm{C}_{\mathrm{YY}}$ & $\begin{array}{c}-124.584 * * \\
(52.119)\end{array}$ & $\begin{array}{l}17.662 * * * \\
(5.484)\end{array}$ & $\begin{array}{l}106.439 \\
(69.763)\end{array}$ & $\begin{array}{l}36.280 * * \\
(15.143)\end{array}$ & $\begin{array}{l}287.591 * * \\
(135.862)\end{array}$ \\
\hline $\mathrm{C}_{\mathrm{LL}}$ & $\begin{array}{l}12847.0 * * * \\
(72.768)\end{array}$ & $\begin{array}{l}237.040 * * * \\
(1.331)\end{array}$ & $\begin{array}{l}712.798^{* * * *} \\
(2.818)\end{array}$ & $\begin{array}{l}5250.37 * * * \\
(21.627)\end{array}$ & $\begin{array}{c}703.734^{* * *} \\
(2.989)\end{array}$ \\
\hline $\mathrm{C}_{\mathrm{YL}}$ & $\begin{array}{l}-41.816 \\
(34.634)\end{array}$ & $\begin{array}{l}-.969 \\
(.731)\end{array}$ & $\begin{array}{l}81.231 * * * \\
(25.220)\end{array}$ & $\begin{array}{l}-35.694^{*} \\
(17.476)\end{array}$ & $\begin{array}{l}87.483 * * * \\
(21.206)\end{array}$ \\
\hline$\overline{\mathrm{DET}}$ & $\begin{array}{c}-.160 \mathrm{E}+07 * * \\
(670645.0)\end{array}$ & $\begin{array}{l}4185.73 * * * \\
(1302.39)\end{array}$ & $\begin{array}{c}69271.1 \\
(49590.9)\end{array}$ & $\begin{array}{l}189208.0 * * \\
(79677.6)\end{array}$ & $\begin{array}{c}194734.0 * * \\
(92994.8)\end{array}$ \\
\hline $\mathrm{MC}_{\mathrm{YY}}$ & $\begin{array}{c}-127.520 * * \\
(52.669) \\
\end{array}$ & $\begin{array}{l}17.734 * * * \\
(5.512)\end{array}$ & $\begin{array}{c}98.900 \\
(66.396) \\
\end{array}$ & $\begin{array}{l}50.413^{* *} \\
(21.055)\end{array}$ & $\begin{array}{l}218.138^{* *} \\
(102.867)\end{array}$ \\
\hline$J$ Test & $\begin{array}{c}123.512 \\
{[.000]}\end{array}$ & $\begin{array}{c}127.010 \\
{[.000]}\end{array}$ & $\begin{array}{c}180.333 \\
{[.000]}\end{array}$ & $\begin{array}{c}140.562 \\
{[.000]}\end{array}$ & $\begin{array}{c}148.302 \\
{[.000]}\end{array}$ \\
\hline
\end{tabular}

Footnotes: see Table VIII. In addition, convergence of the objective function was not achieved in Industry 28 when all parameters were estimated. Hence, $\theta$ was set at its value in Table VIII. 